\title{
Playing rugby: \\ The emergence of talent during the primary and secondary school years
}

\author{
By \\ Helen Hawkins
}

A thesis submitted to Victoria University of Wellington as partial fulfilment of the requirements for the degree Master of Arts (Applied) in

Recreation and Leisure Studies

Victoria University of Wellington 
Don't misunderstand me. I am all for adolescents having dreams, even if they are unattainable. However, there must be some connection between the dream and what it takes to achieve the dream. Without such connection the dream is unlikely to become a reality."

Steven Danish Ph.D.

Steven Danish is a Professor of Psychology, Preventative Medicine, and Community Health at Virginia Commonwealth University in the United States of America and he is the director of the Life Skills Centre at the same university. In addition, Steven Danish is a registered sport psychologist at the Sports Medicine Division of the United States Olympic Committee. 


\begin{abstract}
This explorative study examines the lives of six young men with a talent for playing rugby in order to understand how that talent emerges. The young men involved in this study had all played rugby for a secondary school first XV team and were members of the Wellington Red Tickets Rugby Academy. Semi-structured interviews were conducted to gain information about the young men's general involvement in sport and their perception of the support they had received during their early years, middle childhood years and adolescent years playing rugby. A small group of people comprising secondary school teachers and a parent were also interviewed to provide further insights into how talent is developed within the secondary school rugby system. The young men all discovered they had an aptitude for playing rugby at an early age and in most cases were encouraged to pursue rugby as a main sport by at least one parent and by others in their extended families. The middle childhood years and early secondary school years were characterised by an increasing degree of specialisation, visits to commercial gyms and an array of injuries. The research participants were very determined in their efforts to represent their college at the highest level and by their late adolescent years most in the group were entertaining ideas about becoming a professional rugby player. Stories told by the participants showed that they possessed, to varying degrees, six characteristics that greatly helped their success to date. These characteristics were: (1) awareness that rugby can be a career for only a select few, (2) responsiveness to coaching, (3) ability to set and work towards a long-term goal or goals, (4) decisiveness and an ability to prioritise, (5) valuing the input of others and (6) attractiveness. To date there has been very little research about where an ability to play rugby at the sub-elite or elite level actually comes from. This study about the processes involved in making it into a secondary school first XV team helps to alleviate this situation and has significance to those, like the New Zealand Rugby Union, who have an interest in building up the player base. It also adds to an existing pool of understanding about excellence in sport and has application to those wishing to attain success in any number of other endeavours.
\end{abstract}




\section{ACKNOWLEDGEMENTS}

This thesis is dedicated to John in gratitude for his love and support throughout the course of this project.

I wish to acknowledge Dr Lee Davidson, my supervisor, and thank for her guidance and encouragement. I also acknowledge and thank the six fine young gentlemen who agreed to let me interview them about playing rugby. Many thanks too to the group of rugby enthusiasts who went out of their way to spend a considerable amount of time discussing aspects of secondary school rugby with me.

Many other people have played a part in keeping this thesis moving towards completion. I am deeply grateful for the help received from Noel, Jocelyn, Chris, Kevin, Gary, Hiliary, Kerry and Kirsty. Heartfelt thanks also to Gerard, Jane, Gerardine and Ainslie who provided words of encouragement whenever I needed them. 


\section{TABLE OF CONTENTS}

Abstract iii

Acknowledgements $\quad$ iv

Table of Contents $\quad$ v

$\begin{array}{lll}\text { Chapter } 1 & \text { Introduction } & 7\end{array}$

1.1 Background to the research 8

$\begin{array}{lll}\text { Chapter } 2 & \text { Literature Review } & 11\end{array}$

2.1 Stevenson's approach to studying elite sportspersons $\quad 12$

2.2 Variables influencing expertise in sport

2.3 Adolescent males and sport participation

Summary 28

Chapter 3

Research Design and Methods

3.1 The research approach 30

3.2 The research sample 32

$\begin{array}{lll}3.3 & \text { Data collection } & 37\end{array}$

$\begin{array}{lll}3.4 & \text { Analysis } & 39\end{array}$

$\begin{array}{lll}\text { Chapter } 4 & \text { Findings } & 42\end{array}$

4.1 The early years 42

4.2 Upper-primary, intermediate and early-secondary school years $\quad 47$

4.3 Secondary school - the later years 53

$\begin{array}{ll}\text { Summary } & 60\end{array}$ 
Chapter 5

Discussion and Conclusion

61

$5.1 \quad$ Further research

68

Summary

70

Appendices

Appendix 1: Interview Schedule

72

Bibliography 


\subsection{Introduction}

The All Blacks are one of New Zealand's most successful sporting teams and one of the world's most successful brands (Gilson, 2001). However, to keep on being successful the New Zealand Rugby Union has to not only maintain but also increase its player base or depth. It is possible that a gradual decrease in player numbers at secondary school level could one day result in the All Blacks struggling to be competitive in key competitions such as the World Cup, the Tri-Nations and the Bledisloe Cup.

The central concern of this thesis is to find out about the lived experiences of six young men who attained elite or sub-elite ${ }^{1}$ status in rugby while studying at a secondary school in New Zealand. How their talent ${ }^{2}$ for rugby developed and the actual processes that were followed in order that they could claim a place in their respective secondary school's First Fifteen team are embedded in the study. Examining the role played by the young men's families in influencing their decisions to pursue rugby as opposed to another school sport is also of concern.

Qualitative research methods were used to collect data from several different research participants. In the first instance, individual interviews were carried out with six young men from the Wellington Red Tickets Rugby Academy, ${ }^{3}$ henceforth to be referred to as the Rugby Academy. At a later date, further information was gained from a group of teachers and one parent. These individuals are referred to as the research advisory group in the discussions that follow.

It is my contention that this study is of particular significance to those who have an interest in building up player numbers at the secondary school level and in keeping

\footnotetext{
1 'Sub-elite' is a term used for an athlete who represents their sport at regional representative level and 'elite' is a term used for an athlete who represents their sport at national representative level (Sport and Recreation New Zealand, 2004a).

${ }^{2}$ In this thesis talent is distinct from giftedness. Specifically it refers to the superior mastery of systematically developed abilities (or skills) and knowledge in at least one field of human activity that places a child's achievement well above that of age-peers who are active in that field (Gagné, 1991).

${ }^{3}$ Near the end of 2005 New Zealand Post became the principal sponsor of the Wellington Rugby Football Union's Rugby Academy. The Academy is now known as the New Zealand Post Wellington Rugby Academy.
} 
alive the various traditional competitions that are played between different secondary schools, or groups of secondary schools, each year. Moreover, while this study is sport specific it does add to an existing pool of work about talent development in sport in general. In addition, it has application to those wishing to attain success in other endeavours, sporting or otherwise.

\subsection{Background to the research}

Over the years, I have participated in many sports and as a teacher at a boys-only secondary school I have coached or managed a number of different sports teams. In addition, I am the mother of two boys who during their years at secondary school were heavily involved in a variety of sports; namely athletics, rugby, mountain biking and snowboarding. On Tuesdays I look forward to reading about successful young student athletes, featured in the 'College Sport' section of The Evening Post, now The Dominion Post.

When it came to picking a research topic the four factors mentioned above somehow coalesced and I decided to do something about secondary school students and excellence in sport. During the initial stages of formulating the research question I found I was faced with answering many other questions, for example should the students represent one sporting code or different sporting codes? Is making a regional team 'excellence' or does the student or students need to have been named in a national team? I was making little progress until I moved away from thinking about sub-elite and elite athletes and thought more about athletes working towards becoming sub-elite or elite athletes.

An epiphany of sorts happened as I introduced a new topic to my Third Form ${ }^{4}$ English class. A student raised his hand and said, "Oh Miss, I don't need to do this stuff 'cause I'm going to be a professional rugby player when I leave here." The comment was partly made in jest but my student was also letting me know that playing rugby for a living was something he was thinking about. Moreover, it wasn't

\footnotetext{
${ }^{4}$ While today it is common for those working in the education system to use Year Nine for Third Form, Year Ten for Fourth Form and so on, the research participants referred to their Year Nine year as Third Form and their Year Thirteen year as Seventh Form. Consequently, throughout this research project, I will use this older terminology whenever I am noting a student's year level.
} 
the first time I had heard similar comments from Third Form boys and some Fourth Form boys.

Rugby is an important sport at our college and currently the college has one old-boy who has played for the All Blacks for the past four years and is likely to still be in the team when it travels to France to play in the 2007 Rugby World Cup. Two other oldboys play Super Twelve, now Super Fourteen, rugby and at least three others are paid to play overseas for Japanese company clubs. Another old-boy has just finished playing in the Samoan sevens team. So while on the face of it, playing professional rugby was a possibility for my Third Form student, and the other students who had told me they would play professional rugby, I knew, based on the high attrition rates from rugby through the secondary school years and immediately after leaving college, that the odds of this becoming a reality were not very great.

My scepticism that boys in my classes could become professional sports persons was aided by my awareness that physical activity and sports participation levels for adolescents are in decline (Sport and Recreation New Zealand, 2004b). Still, the boy in question was physically strong and an athletically talented individual. He came from a family where he was probably told he was good if not an outstanding rugby player. He also knew a lot from information, gleaned in the main from newspapers, the internet and popular magazines, about how some rugby players, for example Tana Umaga, Carlos Spencer and Ma'a Nonu, had risen quickly through the different ranks of schoolboy rugby, club rugby and Super Twelve, now Super Fourteen, rugby to finally attain All Black status.

I made a decision to find out about just what was involved in getting into a secondary school First fifteen team, henceforth to be referred to as the First XV team. Moreover, I wanted to have built up a picture about the way successful secondary school rugby players lived their lives. While researching my topic I found information on the Wellington Rugby Football Union (WRFU) website about their training academy. I was pleased to find that, to be eligible for a place at the Rugby Academy, boys had to have played First XV rugby and/or representative rugby. Furthermore, the website noted that the Rugby Academy's aim was to "provide a select group of young players with the skills, discipline, knowledge and attitude 
needed to succeed at National Provincial Cup, Super Twelve level and put them on course for even higher honours - the All Blacks" (www.wrfu.co.nz; June 25, 2003).

All the members of the Wellington Red Tickets Rugby Academy had achieved what my Third Form student needed to do if he was to achieve his dream to play professional rugby. That is, they had made it into their college's First XV team and upon leaving college, had secured themselves a place at one of the fourteen Rugby Academies that exist around New Zealand. I approached Dave Gallagher, manager of the Rugby Academy, and asked him if it was possible to interview a group of young men at the Rugby Academy. Dave Gallagher assured me this was possible and offered to help me make contact with a sizable group of rugby players in their first year at the Rugby Academy. Thus I was able to begin the journey towards completing a thesis on a topic related to sport or recreation.

The focus in the next chapter is on reviewing literature related to how talent in sport develops and emerges over time. The research design and the methods used are outlined in Chapter 3 and the research findings are described in detail in Chapter 4. Certain characteristics that each of the six research participants were found to possess in varying degrees are highlighted in the final chapter along with some ideas for further research. A one page summary brings this research project to an end. 


\subsection{Literature Review}

\section{Introduction}

Talent development as a subject finds a place in the disciplines of both education and sport psychology. Within these disciplines, Bloom's (1985) research into the development of musical, scientific, mathematical and athletic talent stands out. Côté (1999) working on his own, and more recently with others, has extended Bloom's ideas regarding distinct phases in the development of talent in sport. The result has been the formation of a 'framework of talent development' (Côté, Baker, \& Abernethy, 2003; Côté \& Hay, 2002) and references to this framework are made throughout this project.

Research papers reviewed in this literature review relate to a variety of sporting codes. The different researchers have recruited athletes from codes where individual athletes compete against each other and from codes where teams of athletes compete against other teams of athletes. Usually, the researchers have focused on one aspect of sport participation and/or talent development but there are some papers where a range of aspects relating to sport participation and/or talent development are discussed.

The chapter is structured into three sections. The first section is about Stevenson's (1999) approach to finding out why some athletes realise their dream to become subelite and elite athletes and others do not. The second section is significantly larger and is focused on four variables - training, psychological characteristics, familial support and cultural importance - that have been shown to influence a person's ability to gain excellence in sport. The research papers reviewed in this section are mainly about participation in just one sport but there are others that include participation in a range of different sports. While there are some references to papers by New Zealand authors there is a heavy reliance on research that has been done in overseas countries. The final section is about a study by Allison, Dwyer, Goldenberg and Fein (2005) that is specific to adolescent males participating in sport and certain structural barriers that can prevent participation. 
But what about papers that are specific to rugby? Unfortunately there are only four research papers in this review that are related to this particular sporting code. Moreover, one study is about adolescent boys playing rugby in Australia, another is about high school students playing touch in America and the final two are essentially the same study and are also about high school students in America - this time the students are playing gridiron. Certainly, there exist many books about famous rugby players, teams and particular historical moments in the development of rugby, for example Fitzsimons (1996), Palenski, Chester and McMillan, (2006), Romanos and Quinn (1999) and Ryan (2005b) but I could not find any academic literature related to New Zealand youth playing rugby. This is definitely of concern given the high profile that the sport of rugby has in New Zealand society.

The initial decisions made by the participants in this study to play rugby and to play the game the way they did, throughout their time at primary and secondary school, is only a small part of this research project. Consequently, the well known researchers in the field of motivation such as: Duda (1992) [achievement goal theory]; Deci and Ryan (1991) [self-determination theory]; Weiner (1974) [attribution theory] and others, have not found a place in this study. However, motivation has not been entirely ignored. Some research papers pertaining to motivation are included but they have been limited to ones that seek to explain why children and adolescents continue in a sport once they have been introduced to it.

\subsection{Stevenson's approach to studying elite sports persons}

Stevenson (1999) has made the claim that talent development in sport can only ever be discussed from an interactionist position. He explains the interactionist approach as analysing individuals' behaviour from the position that individuals act in their own best interests and are actively involved in the process of formulating a particular identity for themselves (Stevenson, 1999). Stevenson (1999) arrived at this point after reviewing his own papers, especially those that examined athletes and various socialisation factors, and concluding that they failed to provide clear answers to questions such as: "how do athletes become athletes?" and "how is it only some people get to be members of national teams?" (Stevenson, 1999:87). 
The words: 'Entanglements,' used to describe relationships which act to involve an individual more and more deeply in an activity, and 'Commitments,' and a phrase, 'Reputations and Identities,' head up the sub-sections in the findings section of Stevenson's 1999 paper. For Stevenson (1999), these headings describe key stages in the lives of those athletes who make it to the international stage. In addition, Stevenson's (1999) study reveals that most international athletes have aspired to a career as an international athlete for a very long time. To reach their goal, they worked at developing an athletic identity throughout their middle childhood to late adolescent years. Part of their strategy for ensuring success was to involve others in their plans and to work at positioning themselves so they were noticed by those whose job it was to make certain decisions about selections to teams. Moreover, they became adept at finding ways to overcome obstacles that threatened their progress towards short term goals.

Ultimately, Stevenson (1999) suggests that making it in sport involves actively engaging in developing particular role identities that the athlete has perceived as being both desirable and valuable. Interestingly, Côté (1999: 402) cites Stevenson's (1999) findings as being in line with his own findings on children's participation in sport during the early years, or "the sampling years," to apply his terminology. Stevenson's (1999) focus on individual agency rather than on trying to pin-point exact factors that led to the various athletes' success is an approach that has particular significance to this study. However, the huge body of work, much of it produced over the past twenty-five years, focused entirely on determining and measuring the influence of variables affecting the development of expert performance in sport cannot just be ignored (Weiss \& Gill, 2005). Consequently, some studies to this effect are discussed in the next sub-section.

\subsection{Variables influencing expertise in sport}

Baker and Horton's (2004) paper reviews many of the studies written by others on the subject of variables influencing expertise in sport. They suggest that four variables (genetic, biological, psychological or having links to training) have a primary influence on individuals' expertise in sport. They also suggest another seven variables (familial, support, cultural importance, sport maturity, socio-cultural factors, 
instructional resources, contextual factors and depth of competition) can significantly affect proficiency (or otherwise) in sport. Due to the environmental nature of these seven variables, and their interaction with the primary variables, they are labelled as "secondary variables" (Baker \& Horton, 2004: 212).

In this section, literature relating to some of the variables identified by Baker and Horton (2004) is examined. The four variables - training, psychological characteristics, familial support and cultural importance ${ }^{5}$ - are given precedence as they are seen as particularly pertinent to exploring causal factors that helped the participants in this study make it into their college's First XV team; and go on to secure a place for themselves at the Wellington Rugby Academy. Some research pertaining to genetics, biology and instructional resources also finds a place in the discussion.

\section{i) Training}

Baker, Cote, \& Abernethy (2003) mention that many researchers, most notably Ericsson (1996) and colleagues have made the point that in any area of human endeavour, for example chess, mathematics and music, expert levels of performance can only be reached after the performer has undertaken the endeavour for a minimum of ten years. According to Baker and Horton (2004), the often called '10-year rule' has been tested a number of times by different researchers in relation to a variety of sports. Field hockey, swimming, soccer, wrestling and triathlon were used as examples and, in these sports, a strong correlation was found to exist between accumulated hours of practice by an athlete and the level of performance attained by that athlete.

Pugh and Alford's (2004) account of trying to teach touch rugby to a class of secondary school students in the United States is interesting as it endorses the idea that certain basic motor skills and a degree of spatial awareness must be present before there can be any degree of enjoyment when playing sport with and against other people. Pugh and Alford's (2004) students were initially enthusiastic about the new game but struggled with passing the ball and their lack of fitness did not allow

\footnotetext{
${ }^{5}$ For the purposes of this study, cultural importance is largely treated as the importance of sport within boys-only secondary schools.
} 
for the game to be played at a reasonable pace. In the end, the game did not rate as an enjoyable activity.

How to ensure that motor skills and spatial awareness is part of every child's skill-set concerns many researchers. In New Zealand, researchers charged with producing the talent identification and development report, 'Linking promise to the podium, ${ }^{, 6}$ suggest that much more needs to be done in this area during the years when New Zealand children are at primary school. They also call for more studies to be done to do with determining the best training methods for a particular sport or how best to adapt a sport so that it is more accessible to those with general abilities, thus widening the pool of athletes that may go on to higher honours (Sport and Recreation New Zealand, 2004a).

Studies of this type already exist, but often they are very small in scale. Typical of these studies is one by Heitman, Pugh, Kovaleski, Norell, \& Vicory (2005). These researchers endeavoured to find out whether specific practice or variable practice led to higher retention scores of newly learnt motor skills. While the researchers found specific practice did lead to higher retention scores of newly learnt motor skills, they also found that when ability to transfer skills was measured, those research participants who had only been involved in variable practice scored highest. Embedded in the findings is the suggestion that skill development does not have to be focused on repetitive (and at times boring exercises) rather, the same or possibly better outcomes can be obtained by including variable training practices or indeed just playing around with others.

Coaches and others are often surprised when they find that individuals, especially ones thought to be well endowed physically for a sport, have failed over a period of time to reach the standard they had been confidently predicting. Recent assertions by geneticists may help explain this particular scenario. For example, Bray (2000, cited in Baker \& Horton, 2004) argues that the action or expression of specific genes can be altered through exercise. Further, he suggests that certain individuals, due to their inherited genes, can get a lot more from a training regime than some other person who may be doing the same routine.

\footnotetext{
${ }^{6}$ Sir Ronald Scott, chair of the taskforce presented the report.
} 
Biology rates as a factor that can, and does, have a profound effect on aspects of individuals' lives to do with motor and other abilities. Indeed, Lewonton (2000, cited in Baker \& Horton, 2004: 219) sums up human behaviour as "the consequence of a unique interaction between the genes it carries, the temporal sequence of external environments through which it passes during its life, and the random events of molecular interactions within individual cells." Also, the absence or presence of certain debilitating conditions such as migraine, asthma, epilepsy and arthritis is of huge importance when looking into why some individuals experience sporting success and others do not (Bray, 2000, cited in Baker \& Horton, 2004).

\section{ii) Psychological characteristics}

The physical and/or psychological strengths required for success by participants in one sport may not be the same as those required by participants in another sport. While rugby is close to being unique in its ability to cater for individuals of varying physical size and mental abilities in the same team, there does not exist, as noted earlier, any focused research on this matter, especially in relation to children and adolescents playing rugby. Consequently, the literature presented in this sub-section follows a different tack - namely the identification of mental characteristics helpful, possibly essential, to those sports people who wish to perform at a high level in almost any sport. Research by Gould, Dieffenbach and Moffett $(2001,2002)$ into the development of psychological talent in Olympic champions is very impressive and it is reviewed first. This is followed by a review of research concerning psychological factors that help individuals gain entry into sport and motivate them to continue with their sport.

In order to identify what makes an Olympic champion Gould, Dieffenbach and Moffett $(2001,2002)$ undertook a number of different quantitative and qualitative studies on ten Olympians resident in the United States. ${ }^{7}$ Gould et al. (2001, 2002) concluded that they were able to largely verify work done by Williams and Krane, who after extensively reviewing literature in the field of sport psychology in 2001, claimed that certain psychological characteristics can be found in most champion sports people. Their slightly updated list of psychological characteristics common to elite athletes is as follows: (1) an ability to cope with and control anxiety, (2)

\footnotetext{
${ }^{7}$ The Olympians' parents and past and present coaches were also investigated.
} 
confidence, (3) mental toughness/resiliency, (4) sport intelligence, (5) an ability to focus and block distractions, (6) competitiveness, (7) a hard-work ethic, (8) an ability to set and achieve goals, (9) coachability, (10) high levels of dispositional hope, (11) optimism and (12) adaptive perfectionism (Gould et al., 2001, 2002).

Interestingly, it was Gould et al.'s (2001, 2002) study that largely informed the report: Linking promise to the podium, mentioned in the previous sub-section. While at the time of its release the report caused some debate, it has since been used by a number of sporting organisations throughout New Zealand to rewrite policy on the identification of athletes with the potential to win national or international events. ${ }^{8}$

Adolescents today are faced with a great many options with regard to activities they can do during time not allocated to school and study. However, with regard to young New Zealanders, research suggests that engaging in sport is not high on adolescents' lists of preferred options (Dawson \& Ross (2001) cited by McLean, 2005). There are many in government, the health sector and schools who would like the situation to change. However, conclusions from different research papers to do with adolescents' participation in sport indicate that participation in sport (for more than a short period of time) is dependent on a great many factors; including the very complex factor that of motivation (Singer and Orbach, 1999, cited in Baker \& Horton, 2004). The following discussion focuses on presenting findings from a variety of research papers to do with adolescents and motivation to participate in sport.

Bouchard, Lykken, McGue, Segal and Tellegen (1990, cited in Baker \& Horton, 2004), key researchers in the 'Minnesota study of twins reared apart' (MISTRA), have found genetic factors play a significant role in shaping individuals' psychological compositions. Aslo, having certain psychological traits, as opposed to others, can be the difference between having the ability to cope with the pressures that come with being involved in competitive sport and not possessing that ability. Moreover, the MISTRA researchers (1990, cited in Baker \& Horton, 2004) believe

\footnotetext{
${ }^{8}$ Today, identified athletes are referred to one of three Academies of Sport under Sport and Recreation New Zealand's, (SPARC's) umbrella. If accepted they are given 'carded athlete' status, which essentially means that they are nurtured and supported by a team of sporting specialists.
} 
the presence or absence of certain psychological traits can have a profound effect on an individual's ability to be organised and make it to training on a regular basis. ${ }^{9}$

Perceived competence was found to be a major consideration when adolescents are making decisions about whether they should continue to be involved in a sport (Fredricks, Alfeld-Liro, Hruda, Eccles, Patrick and Ryan, 2001; Weiss \& FerrerCajae, 2002). Also, Allison, Dwyer, Goldenberg and Fein's (2005) and Weiss and Ferrer-Cajae's (2002) finding that intrinsic orientations, or mastery, are significantly superior to extrinsic or outcome orientations in adolescent athletes' developing the motivation to stick with training and playing a particular sport is particularly relevant to this study. However, a study by Stiles, Gibbons, Sebben and Wiley (1999) that looked at why adolescent boys dream of becoming professional athletes shows fame and money, very definitely rewards of an extrinsic nature, were the foremost reasons put forward by the boys for wanting to become professional athletes. The chance to be seen in a masculine role also featured highly as a reason for wanting to pursue a professional sporting career. Indeed, the researchers were very surprised that defined outcomes such as "being respected," "having clout" (Stiles et al., 1999: 1082) were the dominant type of response from the research participants and they noted that the boys appeared to lack any understanding about the long hours of practice and the large amounts of game-time needed to become a professional athlete.

Young elite sportspersons from a variety of sporting codes have stated having fun was a primary reason for continuing to compete in their chosen sport (Gould, Feltz, Horn, \& Weiss, 1985; Pugh, Wolff, DeFrancesco, Gilley, \& Heitman, 2000; Scanlan \& Simons, 1992). Challenging their abilities and having social interaction with their peers also rated highly. A point made by Scanlon and Simon (1992), that the actual sources of enjoyment for sports persons can be very different and very diverse is very noteworthy. While this emphasis on fun differs from research cited above that linked adolescents' participation in sport with perceived competence, it does fit very well with the Allison et al.'s (2005) and Weiss and Ferrer-Cajae's (2002) research regarding intrinsic motivation.

\footnotetext{
${ }^{9}$ Research into the way psychological characteristics affect abilities to attain high honours in chosen sports is addressed in the next sub-section and, due to the interaction of "secondary variables" (Baker \& Horton, 2004: 212) psychological characteristics, are mentioned again in the sub-section on familial support.
} 
Peer relationships and an emerging identity also have a profound effect on adolescents' commitment to a sport (Fredricks et al., 2001; Leff \& Hoyle, 1995; Messner, 1990; Smith, 1998). While it may be argued that the issues of peer relationships and emerging identities do not have a place in a discussion examining psychological factors influencing high performance in sport, they have been included because research suggests that adolescents tend to make assessments of themselves and their place in the world by looking at how well they feel they fit in with their peers. In addition, there is evidence to suggest just how much emphasis an individual attaches to needing to fit in will determine his or her subsequent actions to a very large extent (Coleman \& Hendry, 1990).

\section{iii) Familial support}

Support (or not) from within the family has a bearing on individuals' perceptions, expressions and also agency. For this reason a reasonably extensive and varied amount of literature pertaining to familial support is presented in this sub-section. Research pertaining to the issue of burnout in youth sport is presented first. Different researchers' findings into how parents' belief systems impact on children's involvement in sport follow. Côté et al.'s (2003) and Côté and Hay's (2002) framework identifying the changing nature of parents' roles in relation to their child's involvement in sports concludes this sub-section.

For various reasons, for example practice locations and clothing requirements, it is almost inevitable that parents become involved to some extent in their children's sport. The way they involve themselves can either enhance enjoyment or create stresses and anxiety (Hirschhorn \& Loughead, 2000). The latter becoming more evident the more a child is required to perform at prescribed levels which are sometimes unrealistic (Stein, Raedeke, \& Glenn, 1999). Research on whether burnout is to do with personal failure or social stressors found social stressors were to blame in most instances (Coakley, 1992).

Four New Zealand studies, Donaldson, 2000; Harlick, 1999; Harlick \& McKenzie, 2000; Ryan, 1999, have found definite links between parents setting unrealistic goals, parents trying to relive their own sporting success and parents and coaches being too controlling and children experiencing stress. The lives of the athletes in these studies, 
and the lives of the athletes' families, revolved around the athlete's chosen sport. Accounts of parents engaging in obnoxious behaviour and at times violent behaviour towards their child, their child's coach and referees were almost hard to believe (Harlick, 1999; Harlick \& McKenzie, 2000; Ryan, 1999). Behaviour of this kind has led researchers to advocate for the goals of youth sport to be primarily centred on having fun and recognising personal growth through applied effort (Hopper \& Jefferies, 1990; Smith, 1989, cited in Hirschhorn \& Loughead, 2000).

That the influence of parent-coaches on their children's participation, motivation and competitive anxiety was found to be "negligible" (Barber, Sukhi, \& White, 1999: 178) can be seen as very good news for the children involved. It is also good news for sports administrators who greatly rely on parental help for coaching teams, especially those in primary competitions (Wiersma \& Sherman, 2005). In many ways, what was being studied by Barber et al. (1999) was a particular type of parental-led socialization into sport process. Brustad (1996) and Kimiecik and Horn (1998) are three researchers who have undertaken studies to find out more about parental-led socialization processes as they believe that the answer to why some children get involved in sport and others do not lie in understanding these processes.

The 'Family Influence Model' was used to guide Kimiecik and Horn's (1998) research into the relationship between parents' beliefs and children's moderate to vigorous physical activity (MVPA). While no relationship was found to exist between parents' exercise behaviour and children's MVPA participation it was found that parental beliefs, especially perceptions regarding their child's competence and task orientation, were significantly related to the amount of MVPA that the children engaged in. Kimiecik and Horn (1998) were not hesitant in predicting that as the children in their study moved into adolescence their MVPA levels would not change significantly, due in part to the continued influence of parents, particularly the influence of mothers during each child's formative years.

Brustad's (1996) examination of the relationship between parental socialisation and children's interest in physical activity differs from the Kimiecik and Horn (1998) study in that gender is examined to a far greater degree. In summary, Brustad (1996) found that parental belief systems were more instrumental in helping children stay 
involved in sport than parental role-modelling behaviours per se. And for boys, the parental variables most instrumental in ensuring a positive result were perceived parental encouragement and perceived physical competence. For girls, a positive result appeared to hinge on perceived parental encouragement and perceived parental enjoyment working together. To ensure misunderstandings are kept to a minimum once children are involved in sport, Stein et al. (1999) suggest parents spend time discussing with their children the level of involvement they want their parents to have in their sport. They also note that parents need to be prepared for their children to say they want a different type of involvement from their mother than from their father (Stein et al. 1999).

The multi-faceted nature of parental involvement in children's and adolescents' sport is the focus of studies by Hemery (1991), Côté (1999), Côté, Baker and Abernethy (2003) and Côté and Hay (2002). Taking a lead from Bloom (1985), these researchers are primarily interested in the journey taken from beginning in a sport to the time when the athlete can consistently manifest a high level of performance in their sport. Hemery's (1991) decision to explore the influence of family, friends and key personnel attached to an athlete was, at the time, very innovative. His conclusions, regarding psychological characteristics common to athletes who achieve highly in a sport, are remarkably similar to those put forward by Gould et al. (2001, 2002).

Côté et al. (2003) and Côté and Hay (2002) developed a framework to show the different stages athletes normally move through and the roles the parents of athletes typically take up. Three stages are identified and described. These are: the sampling stage, the specialising stage and the investing stage. In the first stage, Côté et al. (2003) and Côté and Hay (2002) framework shows parents as instigators and active participants in planning their child's entry into sport. The next stage finds parents in the role of providing finance and general advice and by the final stage the parent's role becomes one of dispensing high amounts of emotional support in an attempt to mitigate against certain pressures that come with competing at a regional and/or national level. Over time, various decisions, once the prerogative of the parents, become the prerogative of the coach. 
MacPhail and Kirk (2006) made it their mission to explore four characteristics of the 'specialising' stage as defined by Côté et al. (2003) and Côté and Hay (2002). They did this within the context of a children's athletic club in England's Midlands. Their paper was very focused, and examined reduction in the number of sport and leisure activities (by the children) as they become more involved in athletics, enjoyment, success and competition, deliberate practice and the support given (to the children) at the specialising stage. According to MacPhail and Kirk (2006), the quality of the sporting experience, not quantity, is the key to keeping young people in sport during the 'specialising' stage. They also suggest that national sporting organisations should endeavour to mix their generally prescriptive models for children's sport with more ecologically informed approaches, as these are more grounded in the reality of young people's sport.

But what else is happening as athletes transition from the 'specialising stage' to the 'investing stage'? Throughout Donaldson's (2000) thesis, about the lives of sub-elite and elite high divers, the reader can feel the researcher's concern for her research participants, one of whom is her son. Her concern centres around the fact that young people involved in this sport had over time become extraordinarily dependent on their coaches for all manner of decisions. The general acceptance by the research participants that the coach always knew best was shown to have resulted in some of the athletes experiencing uncertainty about emerging identity, being unable to socialise with others outside their sport and suffering painful injuries of the type associated with overtraining (Donaldson, 2000).

\section{iv) Cultural importance}

The importance a society places on a particular sport can have "a significant influence on any success achieved (in that sport)" (Baker \& Horton, 2004: 220). The reasons why one sport (and not another) becomes important in a society are different for different societies. However, it is generally accepted that a sport's suitability to the characteristics of the people, the natural environment of the region and the length of time it has been played in the region have a considerable influence (Baker \& Horton, 2004). While a number of books exist, for example Reed and Swan (1969) and Ryan (2005a), about rugby and New Zealand society a review of such books is not necessary to this study. Of more importance is the fact that the research participants 
in this study all developed their craft while attending one of the many boys-only secondary schools that exist throughout New Zealand. Consequently, the focus throughout this sub-section is on literature that helps to explain the place of sport in boys-only secondary schools. After a general introduction, an overview of sporting culture inside two different schools, one in the United States and one in Australia, is presented. Following this, Lashlie's (2005) observations bring the focus back to New Zealand. Literature relating to self concept theory and coaching practices in New Zealand secondary schools brings the sub-section to a close.

Coakley (1998) reviewed literature on justifications given for the high status of sport in American high schools. He found the following six justifications dominated the literature. Sport:

- involves students in school activities and increases interest in academic activities;

- builds a responsibility achievement orientation, and enhances the teamwork skills required for occupational success;

- provides fitness training and stimulates interest in physical activities;

- generates the spirit and unity necessary to maintain the school as a viable organisation;

- promotes parental, alumni, and community support for all school programmes; and

- gives students opportunities to develop and display skills in activities valued in the society at large.

While interesting, Coakley's (1998) own research, and that of McNeal (1995, cited in Coakley, 1998) and Marsh (1993, cited in Coakley, 1998), gives a better understanding of the relationship between secondary schools providing sporting opportunities and adolescent behaviour. Specifically, sport facilitates engagement with the provider. The more heavily a student is involved in a sport (or sports) the more likely he or she is to stay committed or loyal to their school. Also, the sports setting provides a different context for students to "develop and display their 
competence" and be "noticed and rewarded" for that competence (Coakley, 1998: 445). Moreover, when students "hook-up" (ibid) with one or more adults involved in their sport they often find someone who can provide them with information and ideas about how to move forward in the world when they leave school.

The research by Coakley (1998) and others, showing positive correlations between participation in sport and increased identification with the school, helps support the often-heard argument that more sport is needed in schools. However, other researchers, for example Rees, Howell and Miracle (1990, cited in Coakley, 1998) and Fejgin (1994, cited in Coakley, 1998), are not so sure. These researchers contend that school sporting competitions tend to attract those students who already possess the characteristics that are often associated, by teachers and others, with ability to obtain a high degree of academic and social success while at school. Noting this phenomenon, there is possibly a case for different sports to be introduced to schools to attract those students who are not keen to participate in whatever codes are already on offer.

Working against this actually happening is the fact that, in both large and small schools, past practice and pressure from the community can put limitations on the introduction of new practices to a considerable extent (Jackson \& Bisset, 2005). The cultural practices surrounding certain sports may take an even longer time to change because very often the personnel involved have participated and enjoyed similar practices in their youth. Two studies, one exploring football culture in a school in a small town in the United States by Foley (1990a, 1990b) and another exploring rugby culture at a large independent boys-only school in Australia by Light and Kirk (2000), detail particular practices related to the sport of football and rugby respectively. When read in full, it is possible to detect the reasons why the research participants in these studies came to be so involved in their particular sport.

In the school where Foley (1990b) based his study, the group known as the 'football players' is described as having a 'work hard play hard' mentality. Within both the school setting and the wider social setting the 'football players' involve themselves in "identity performances" aimed at enhancing their status as athletes with other students and with adults. Foley (1990a, 1990b) concluded that the behaviour of the 
footballers, and the behaviour of other identifiable groups within the school, was grounded in class, ethnicity and gender. After noting how the selection practices for both players and coaches were located in class and race with gender as a given he contends that the school is a site, indeed a major site, for the reproduction of various forms of social inequality within the town where the study took place.

Similarly, Light and Kirk (2000) set out to expose the discourse and corporal practices within one school known for being very competitive in a particular sport. While Foley's (1990a, 1990b) study is quite wide ranging, Light and Kirk's (2000) study is narrow in its intent. Specifically it is about the confirmation of their theory that rugby is a vehicle for social education. Light and Kirk (2000: 173) found that rugby was a central element of the school's curriculum, and practices "connected to ideals of physical domination, competitiveness, toughness, teamwork and selfrestraint" that constituted rugby culture within the school were both class specific and very focused on the body. The role of the body, especially in competitive displays of skill and strength, can play an essential part in the formation of a particular masculine identity from a very early age (Swain, 2000, 2002). Light and Kirk (2000) concluded that rugby had a certain symbolic value within the school and was used to reproduce successive generations of boys who exhibited behaviours associated with a certain, some might say 'traditional,' form of masculinity.

Foley (1900a, 1900b) and Light and Kirk (2000) found that the football and rugby culture within the two schools that they studied was grounded in history, ritual and physicality. In addition, for many of the boys who attended the schools, football and rugby culture provided them with a certain identity that excluded them having any other identity within their school. With very little research on rugby culture in New Zealand secondary schools available, the studies by Foley (1900a, 1900b) and Light and Kirk (2000) are included because they do at least provide some insight into young men playing a sport that involves running, passing the ball, tackling and scoring points. In this way, they help set the scene for examining data provided by six young men with a passion for playing rugby all of whom attended boys-only secondary schools in New Zealand. 
Lashlie (2005) is definitely writing to counter certain negative images of boys in New Zealand and defend their interests. ${ }^{10}$ Lashlie (2005) reports how she was largely unprepared for finding that sport, whether formal or otherwise, was hugely important in all the schools she visited during the course of her study. She notes how at times the physicality of boys on mass overwhelmed her and the level of enjoyment the boys experienced while playing sport surprised her. Lashlie (2005: 45) concludes that sport is something boys' schools do "exceedingly well" and adds that "for the vast majority of boys, sport is an integral part of the journey to manhood". Lashlie (2005) supports her last statement by saying sport is an activity where a boy can get a feeling of being involved in something bigger than himself. Lashlie (2005) also talks about boys who involve themselves in singing, dancing or playing an instrument, alongside, or even instead of, sport ${ }^{11}$ and notes again how involvement in such activities brings them into contact with a variety of adults.

This observation is important as it provides evidence that supports a claim by Mac an Ghaill (1996) about the formation of identity. Mac an Ghaill (1996: 394) write that schools do not produce masculinities in a direct, overly deterministic way. Instead, he contends the construction of students' identities is an "active process of negotiation, rejection, acceptance and ambivalence". While Mac an Ghaill's (1996) theory does not totally reject the notions that assumed and acted out identities are shaped by class and ethnicity, he appears to suggest that individual choice can play a part as well.

Attrition, or 'dropping out' of sport, is not the focus of this research but it does sit in the background and a research paper focused on this topic is examined in the next section of this literature review. For now, it is important to note that having a good a sense of self worth is essential to the development of functional individuals (Fergusson, Lynskey, \& Horwood, 1994; Howard \& Johnson, 2001). Also, the "evaluative dimension" that can enhance self-esteem can also cause certain

\footnotetext{
${ }^{10}$ Growing Gorgeous Boys into Good Men, was written by Lashlie after she had finished a project (commissioned by the Association of Boys' Schools in New Zealand) aimed at finding out what made boys' schools different, what they did well and ways they could improve in their preparation of their students for the world. Lashlie visited 180 classes of boys in 25 schools to collect initial data.

${ }^{11}$ To some extent Lashlie's (2005) study reflects how aspects of new National Curriculum, introduced into New Zealand schools during the 1990s are being realised in primary and secondary schools throughout New Zealand.
} 
individuals to withdraw (Coleman \& Hendry, 1990: 53). Howe (1990), a respected coach and educator, suggests that all physical education personnel and coaches in schools become familiar with Bandura's self-efficacy theory of motivation and work towards ensuring that they enhance, not destroy, self-efficacy among their students. ${ }^{12}$ Howe (1990) also recommends that physical education personnel and coaches provide students with sufficient time to perfect the critical skills, orchestrate opportunities for students to work with older students and provide immediate feedback when students perform tasks well.

Paterson's (1999) research can be seen as a reminder that even though sport science has developed as a subject in recent years, many coaches in New Zealand have little perception about the impact their comments and methods have on their students' selfperception. To remedy the situation, Patterson (1999) suggests coaches be educated about the benefits of reflecting on their own coaching behaviour. It is conceded that innovative coaching courses, run through organisations such as SPARC and the WRFU, probably include instruction in self assessment.

\subsection{Adolescent males and sport participation}

Allison, Dwyer, Goldenberg and Fein's (2005) paper about adolescent males and sport participation informs this final section of the literature review. In a similar way to Stevenson (1999), Allison et al. (2005) advance the theory that particular decisions made by persons can be crucial to their development as a person who not only participates in sport but also excels in their chosen field. The researchers also make the point that the timing of these decisions can be critical to athletes' future success in a sport.

Allison et al. (2005) put forward the thesis that male adolescents' involvement in sport (or not) is the result of many factors intersecting with each other making one pathway, or set of behaviours much more desirable than the others on offer. Again, a number of links to Stevenson's (1999) paper are evident. However, Allison et al. (2005) analyse the situation in more detail than Stevenson (1999). In the first instance, they show that age, gender, ethnicity and class are correlates and predictors

\footnotetext{
${ }^{12}$ Self-efficacy is described as "the individual's belief at being able to accomplish a task successfully" (Howe, 1990: 5).
} 
of physical activity. This is not entirely new, but Allison et al. (2005) move on to show that when age, gender ethnicity and class are examined alongside each other something more potent emerges. For example, the age 'sixteen years' can become more potent when it is combined with gender and the availability of a car to drive courtesy of saving monies earned by being in part-time employment.

Allison et al.'s (2005) findings in relation to adolescent boys withdrawing from physical activity are particularly interesting. Their research shows decisions made by boys to 'drop out' of sport are linked to the wider meanings of gender and age. The foremost reasons were reported as: (1) boys wanting to shield their developing body from being scrutinised by their peers and (2) boys' real and imagined lack of skills compared to their peer group. Other reasons emerging from the research and related to the combination of gender, listed in no particular order, are: (1) pressure from parents wanting their sons to use their time for academic study, (2) the boys' own desire to improve their classroom performance by spending time studying, (3) wanting to fit in with their peers and (4) role-overload. ${ }^{13}$ Certain structural determinants, such as cost and access, are also noted in this study but overall, the role of individual agency in determining continued participation in sport is endorsed.

Stevenson (1999) and Allison et al.'s (2005) studies provide interesting perspectives for any examination of the processes involved in becoming a sub-elite or elite athlete. Together these studies suggest that for athletes to move forward they must first get fully involved or "entangled" (Stevenson, (1999) in their sport and fulfil various obligations. Moreover, they must plan, act in ways that elevate athletic identity, challenge certain decisions and be prepared to engage in a degree of politics relating to their chosen sport.

\section{Summary}

The literature review began by introducing Stevenson's (1999) research on why some athletes make it into elite teams while others, often with a similar degree of talent, fall by the way-side. His interactionist perspective for studying elite sportspersons is seen as very relevant to this study. The second section began by acknowledging Baker and

\footnotetext{
${ }^{13}$ Role-overload was shown to be related to having a part-time job, being involved in a relationship or having certain home based responsibilities.
} 
Horton's (2004) study investigating factors that affect the development of expertise in sport. Literature pertaining to four of the variables identified by Baker and Horton (2004) (training, psychological characteristics, familial support and cultural importance) was reviewed to provide background knowledge to how sporting intelligence develops and is maintained during athletes' childhood and adolescent years. The final section of the literature review focused on recent research by Allison et al. (2005) which discussed the influence of certain structural and social determinants on adolescent males' initial involvement in sport. This study was highlighted as its findings have particular implications for the development of a strong player base or depth in male-dominated team sports. Overall the literature review shows that talent development in sport cannot be viewed as something that develops in a predetermined, definite or linear manner.

The introduction to this chapter noted that there is a scarcity of research in New Zealand about children and adolescents who are heavily, or even moderately, involved in rugby. This is not to say there is no literature on rugby rather the dominant focus of the research to date has been on the role rugby has played in defining masculinity in New Zealand and shaping communities in New Zealand and elsewhere (Phillips, 1994; Phillips, 1984, 1996; Vincent, 2005). Added to this, and already alluded to, is the huge volume of literature that glorifies certain players or teams or seeks to explain particular developments in the game.

In order to inspire growth in the sport at all levels, there is a need for academic studies aimed at understanding children's and adolescents' playing conditions in New Zealand. While this study is small in scale, it will add to a growing body of literature about gaining excellence in sport or developing sporting intelligence. In addition, it will help to fill a gap that presently exists about children and adolescents playing rugby. The research method chosen for this study and details about how the research was conducted are discussed in the next chapter. 


\subsection{Research Design and Methods}

This chapter begins with a discussion about two distinctly different research methods. Included in this section is my argument that in order to understand how a talent for playing rugby emerges, qualitative research methods, as opposed to quantitative research methods, are the better option. Three further sections follow the discussion on the research approach. The first section provides details about the research sample, the second describes the data collection process and the final one notes the procedure used to analyse the data.

\subsection{The research approach}

The methodology used for examining human behaviour has become more diverse in recent times. How feminist theory, coupled with post-modern sensibilities, has worked to challenge the predominance of the positivist approach to research has been noted by a variety of authors (Heisenberg, 1958; Keller, 1985; Habermas, 1989, cited in Maykut \& Morehouse, 1994). The essence of the positivist approach is that there is only one true answer to any question, and that the researcher's responsibility is to find that truth. To find out how and why such a stance became so dominant it is necessary to understand that different people hold very different assumptions about the nature of existence and reality, knowledge, human nature and "teleology," or life's purpose (Maykut \& Morehouse, 1994: 4).

In the social sciences, certain assumptions held by a researcher about the nature of existence and the nature of reality will impact strongly on the methods used to research his or her subject (Burrell \& Morgan, 1979). Researchers who subscribe to the idea that reality is something that exists externally to the individual are sometimes termed "external-idealists" (Henderson, 1991: 13) and will be drawn towards using positivist methods for their research. Other researchers, namely those who consider reality to be individually constructed, will tend towards using research methods from within the interpretive tradition.

Researchers' thoughts about the nature and the status of knowledge (Silverman \& Morehouse, 2005) and ideas to do with human nature will also impact on the methods 
used to research a given subject and any explanations tendered about linkages between certain pieces of information or "units of meaning" (Maykut \& Morehouse, 1994: 128). For example, researchers who begin their research projects believing one event can cause another event will also likely assert that explanations from one time and place can be generalised to other times and places, and that their propositions can be verified with testing. On the other hand, if researchers begin their research believing certain events shape other events the explanations they give about human behaviour will tend to be presented as tentative and at best applicable to one time and one place. The former stance arises from a "deterministic view" of human nature and the latter stance from a "voluntaristic view" with the research participants presented as controllers with a sense of agency, autonomy and free will (Sparkes, 1992).

The purpose, method, overall design of this project and the way this project's data is presented owes much to my philosophic perspective which is neither deterministic nor voluntaristic but is somewhere in between. This view has been largely shaped by my many years teaching initially in primary schools and latterly in the oldest catholic boys-only school in New Zealand. Here the walls are lined with photographs of past and present students who availed themselves of opportunities within the college environment to bring about changes in their lives. Yet over the years, I have worked with many students who, for a variety of different reasons, cannot or do not want to participate fully, or sometimes even partly, in the programmes the school has on offer.

Methodologies which treat the social world as being hard, real and largely external to the individual do not fit this particular research project as the subject matter is very much part of the culture of the school I work in, especially during the winter terms. Thus, in order to find out what was involved in getting into a secondary school First $\mathrm{XV}$ team and how successful rugby players lived their lives, another type of methodology is called for; one which allows me to get close to my research participants in the hope of gaining an in-depth understanding of their lived experience (Sparkes, 1992). Accordingly, the research methods that are used in this research: individual semi-structured interviews and interviews with the members of the research advisory group, sit firmly within the interpretive position. Furthermore, these methods fit well with Stevenson's (1999) assertion that researchers wishing to 
unravel the reasons why some athletes, and not others, achieve high honours in sport should approach the subject from an interactionist position. Stevenson (1999) came to this reckoning after "giving questionnaires of all sizes and descriptions to all sorts of different athlete groups" over a period of some ten years and still feeling that he hadn't been able to fully make his way into the social world of the athlete or understand how certain choices were made (Stevenson, 1999: 86).

Henderson (1991) warns beginning researchers of recreation, parks or leisure phenomena to be cautious about accepting qualitative methods as better, easier or even more appropriate, than quantitative methods. While I have taken Henderson's (1991) warning into consideration I have also been influenced by Janesick (2003). She stated that the presentation of solid descriptive data is an effective way to lead the reader towards an understanding of the meaning of the experience under study. However, I acknowledge that, like all those who align themselves with grounded theorists, I am constructing "an image of a reality, not the reality - that is objective, true, and external" (Charmaz, 2002: 273).

In summary, proponents of quantitative studies claim their work is done from "within a value-free framework" (Denzin \& Lincoln, 2003: 13) but I am unable to approach the topic of school boy rugby in this way. Also, the idea that my findings can be reduced to independent variables in order to facilitate their measurement is not consistent with the intent of this research project. Finally, I take heart from Andrew Sparkes (1992), researcher in Physical Education at the University of Exeter, who believes that researchers in the physical education and sport sector have been slow to employ qualitative methodology when undertaking research projects. He urges researchers to consider using this type of methodology to ensure that theoretical vitality and validity is enhanced within the sector and understanding is increased outside the sector.

\subsection{The research sample}

\section{i) The research sample}

Six members of the Rugby Academy were chosen to take part in individual semi- 
structured interviews. Those wishing to be considered for a place at the Rugby Academy must show the selection panel that they possess:

- potential to play for the Vodafone Wellington Lions, Hurricanes or even a higher status team;

- motivation and commitment to succeed on the field and

- motivation and commitment to succeed with tertiary study or with a chosen pathway to a career (Wellington Rugby Football Union, 2003).

\section{ii) Sample criteria}

The sample was structured to be, so far as was practicable, characteristic of the 2005 Wellington Hurricanes team in terms of their ethnicity. Three further criteria were used in the selection of interviewees. These were: (1) the interviewees had to have left school having completed a Seventh Form year in either 2003 or 2004, (2) the interviewees had to have played First XV rugby while at college and (3) the interviewees had to have been schooled at different colleges if at all possible.

\section{iii) Rationale}

The Third Form boy, spoken of in chapter one, who voiced his desire to be a professional rugby player lived in Wellington and, at the time I began this research project, had just completed his first enrollment form to play rugby for his college. The weigh-in to confirm eligibility for different teams was about to take place. By engaging members of the Rugby Academy as research participants it was thought the interviews would be with young men who had in effect completed the journey this Third Form boy, and some others, were planning to undertake during their time at college.

Also, by enlisting young men who had attended different colleges, the interview data would likely cover a range of different experiences related to playing rugby. The stipulation that potential candidates must have recently left school ensured research participants would likely be able to remember their time at school in detail.

Matching the sample criteria with the ethnicity of the 2005 Hurricanes team was an attempt to ensure the research sample did not result in one that contained participants from only one ethnic group and/or social background. I note the mix of ethnicities of 
the players in each Super Twelve, now Super Fourteen, team in New Zealand, with the possible exception of the Canterbury Crusaders, is varied. In saying this it is also likely that in each team a great many players would identify as having Maori, Pacific Island or European ancestry and this particular mix of ethnicities is reflected again in All Black teams of recent years.

Information for making an estimate in terms of ethnicity within the 2005 Hurricanes team was gathered by downloading profiles of team members from the WRFU website. The limitation of this method of analysis is that the way the different team members are categorized may be inaccurate, and with more time, asking for information from the WRFU may have been a better option.

\section{iv) Sample selection}

I approached Dave Gallagher, manager of the Rugby Academy, for permission to visit the training school and ask members to become research volunteers. Permission was duly given and issues to do with availability of potential research volunteers were discussed. ${ }^{14}$ It was decided I would write a brief outlining the research aims, my background and criteria relating to the type of rugby player that was being sought by me for my research project. The brief would have a paragraph noting that all information gathered from research volunteers would be treated by me as highly confidential. In addition, I would note that in any papers I might publish names would be changed to ensure anonymity. At the bottom of the brief would be a form for Rugby Academy members, interested in being approached as future research participants, to fill out. The form would ask for a name, contact phone number, the name of the last school attended and the final year at that school.

It was agreed that Dave Gallagher would read this brief out at one of his weekly meetings for first and second year members of the Rugby Academy. The brief and associated form would then be handed out to interested persons. They would be instructed to read the brief again, and if happy to be contacted by me, complete the form and return it to Dave Gallagher by the end of the week. Dave Gallagher would put any forms he received into an envelope marked with my name, and the envelope

\footnotetext{
${ }^{14}$ While at the Rugby Academy most members are expected to complete papers at tertiary level or have an apprenticeship of some kind. They attend Academy training sessions each morning and training sessions for their Wellington club two or three evenings a week.
} 
would be picked up by me after a suitable period of time. The WRFU website noted nineteen rugby players had been accepted into their academy at the start of 2005 . Consequently, twenty request forms were given to Dave Gallagher and the process discussed above was worked through and completed within a four-week time frame.

Twelve Rugby Academy members volunteered to become potential research participants. I selected eight rugby players by following these steps: (1) folding the request forms and dropping them in to a box, (2) shaking the box and (3) taking out eight forms. I opened each form and guided only by the individual's surname placed them into one of the following four categories: Pacific Island, of Maori descent, New Zealand European or other. This process resulted in four players in the Pacific Island category and four in the New Zealand European category. I decided that this sample would suffice as, according to my reckoning, the 2005 Hurricanes team was fairly evenly split between Pacific Island and New Zealand European rugby players. ${ }^{15}$

I rang the first three players from the Pacific Island category and all agreed to meet with me some time in the next fourteen days. I then rang the first three players from the New Zealand European category and two agreed to meet within two weeks and another was scheduled to meet three weeks out. The two remaining forms were put back into the box with the other forms. The box was then put to one side. If a new candidate needed to be selected for some reason, for example someone needed to be out of Wellington for a period of time or someone's ethnicity was markedly different to the one I had ascribed to them, the process outlined above would have been put into action again.

\section{v) Profiles of the research participants}

The research participants had been assured of anonymity on the initial form requesting their assistance. Accordingly, names have been changed in the passages below.

\footnotetext{
${ }^{15}$ At the beginning of the 2005 season I calculated that the number of Pacific Island players in the team was only marginally higher than the number of New Zealand European players but there was one player whom I categorized as being 'of Maori descent'.
} 


\section{Ben}

Ben is nineteen years old and is of New Zealand European descent. He grew up in one of Wellington's northern suburbs and has one younger sister. Ben's father adores anything to do with rugby and his mother also follows national and regional teams. This year Ben began a degree at university and is taking papers in mathematics, commerce and history.

\section{Alehana}

Alehana is nineteen years old and identifies himself as Samoan. Although Alehana is an only child there were always cousins around when he was young and living in one of Wellington's new sub-divisions. His family shifted to an older suburb in Wellington when he was nine years old and when Alehana turned thirteen he became

love to watch rugby. Presently he is studying law at university in Wellington.

\section{Isiah}

Isiah is twenty years old and was born in Samoa to Samoan parents. After spending approximately two years in Australia Isiah's family moved to New Zealand when Isiah was eleven years old. Isiah is an only child and after living in a city close to Wellington, his family moved into a Wellington city suburb when he was fourteen years old. Having just returned from an overseas tour with the New Zealand Under21 team, he has yet to make a decision about whether to begin university this year.

\section{Tariu}

Tariu is Samoan and the fourth and youngest boy in his family. He is twenty years old. A sister, just one year older separates Tariu from his three older brothers. Tariu grew up in one of the cities close to Wellington and says that he came from "a basketball family". Having just returned from an overseas tour as a member of the New Zealand Under-21 team and, with other rugby commitments already in his diary, Tariu has decided to postpone beginning tertiary studies until next year.

\section{Davy}

Davy is nineteen years old and is the oldest in his family. He is New Zealand European and lived with his parents and two younger sisters in a province near 
Wellington until late last year. Davy's father has been a passionate rugby player for many years. Davy has only recently moved to Wellington and is undertaking a bridging course at university. If all goes well he intends to start studying for a Bachelor of Arts degree next year.

\section{Paulo}

Paulo is twenty one years old and when asked if he identified as Samoan or New Zealand European he explained that his mother was Samoan and French and that his father was Samoan, German and Chinese. From around the age of three, he has lived in a city close to Wellington. Paulo's father has always been very interested in sport and introduced his son to many different sports when he was growing up. Paulo's father moved overseas a few years ago. Paulo and two of his four sisters have moved away from the family home. Paulo will begin taking papers towards a university degree later this year.

None of the research participants were married and none had dependants.

\subsection{Data collection}

\section{i) Setting up the interviews}

After the six rugby players had been contacted by phone a letter was forwarded to them thanking them for responding to my request for volunteers and reminding them about the date and time of their interview. A formal consent form was included in the envelope. If the rugby players wished to continue in the research project they were asked to read it, sign it and bring it with them to the interview. My contact details were listed in full. No person in this initial group rang me or made a decision to not keep their interview appointment.

\section{ii) Interviews with the research participants}

Four interviews took place in the late afternoon in an interview room at the college where I teach. The location was chosen as the research participants knew the school, having visited it in some capacity on previous occasions and could attend training immediately after the interview. ${ }^{16}$ The other two interviews took place on different

\footnotetext{
${ }^{16}$ The college is close to two prominent Wellington rugby club training fields.
} 
afternoons at Victoria University. A room in the department I was enrolled with was the setting, and again convenience for the young men concerned was the main reason for picking this location. Both rooms used were quiet and well suited to a formal or semi-formal discussion. The six interviews were completed over a four week period and the length of time for each interview ranged between fifty-five minutes and one hour fifteen minutes.

A schedule of questions and prompts were taken to each interview (see Appendix 1). This served to ensure that similar topics were covered in each interview and certain details about the participants' families were gathered. All the research participants were relaxed and gave detailed answers to the questions. The flow of the discussion was facilitated by the interviewer, but latitude was given when participants provided additional information or took the discussion into unforeseen areas.

From the time of my initial contact with the research volunteers they were informed that the interview sessions would be taped. None of the young men objected to this or showed any concern while the taping device was being set-up. At the end of the interviews all the research participants were thanked and told that when the interview transcripts were typed they would be sent a copy. Their copy could then be reviewed and commented on if they so wished. One participant wanted to know if he had talked the most.

\section{iii) The use of a research advisory group}

The method of asking a few targeted individuals for comment was included to help verify and possibly to put into context certain information gathered from the research participants. Six persons were approached to be participants at two informal meetings to be held in the staff room of the college where I work. Each person was given a brief outline of my research project. Following verbal consent, each person was given a formal form to sign indicating their consent to take part in the research project. My agreement to keep their identities confidential was included on this form. Members of the research advisory group were told they would not be quoted per se, rather their views were being gathered to help me locate, or find a context, for particular statements made by the research participants. 
Five members of the research advisory group were teachers and one was a parent of a First XV player. Four of the five teachers had taught over a period of some years at a college attended by one research participant and one of the five had taught at a college attended by three research participants. All five teachers had over the past ten years coached or trained a First XV team for a set period of time at their respective colleges and one teacher had acted as mentor to one of the research participants. Of the teacher group, four were male and they all played First XV rugby when they attended college. (Two had gone on to play at provincial level while another funded his overseas travel by playing rugby for a team in England.) The female teacher in the group has played in a number of high profile women's rugby teams in the past and was hoping she would be selected for one such team again this year. The parent of a First XV player had been a team manager for his son's team in the past.

The members of the research advisory group were spoken to as a group on two occasions. At each meeting, I began the discussion by telling the group where I was at with the project and asking them to comment on two or three of the comments made by the research participants. The discussion that ensued was informal and largely circular, meaning one person would offer a comment and another person would add to it, followed by another person until everyone in the group had said something. I did not record the discussions but wrote notes immediately after each meeting had finished. It is felt that the perspectives of the members of the research advisory group added greatly to the research project, especially their views on rate of injury and the impact injury often had on the make up of secondary school rugby teams and the weekly results at key times during the season.

\subsection{Analysis}

\section{i) The process}

Verbatim transcripts of each taped interview were made by a professional transcriber. The transcripts were stored on compact disk and two copies of each transcript were printed. After reading through the transcripts, a profile of each research participant was written noting points about their family, actions taken at school and recollections of playing sport while being at either primary, intermediate or secondary school. Ideas given about where they thought their rugby would take them were also 
included. The profiles were used as quick reference papers during the analysis and writing up stages of the project.

The six interviews were analysed using the constant comparative method (Glaser and Strauss, 1967; Lincoln and Guba, 1985, cited in Maykut \& Morehouse, 1994). Each line of each interview was read and potentially useful "chunks" of information were collected (Maykut \& Morehouse, 1994: 128). This was done by acquiring a large sheet of paper and recording actual bits of information along with the participant concerned or making brief notes about certain pieces of information and recording the place the information could be retrieved from. A total of 144 potentially useful pieces of information were highlighted. These pieces of information were sorted into fifteen groups. The headings given to each group, such as 'fathers' and 'working out,' emerged from a feature common to the grouped pieces of information. One further heading, named 'other,' was used for a few the 'hard to place' reflections. Some of the information gained from the research advisory group found a home beside some of the different groupings.

When the groupings were examined it was found they could all, with the exception of 'other', be grouped into one or other of the following categories: environmental influences, namely family, school and community; activities specific to the world of sport, for example injuries sustained while training; or activities commonly undertaken by young people, such as parties, study, and thinking about ways to earn a living. The three categories were interesting and could have been used to structure the chapter discussing the findings. However, I also noticed the pieces of information could sit fairly neatly along a physical growth continuum. On separate pieces of card I noted three headings: early, middle and senior. I now placed the gathered pieces of information under these headings. From here a total of nine themes emerged and each of these is discussed in the following chapter. The developmental approach to the discussion sits well with the idea that sporting talent can emerge at different points in an athlete's life (Sport and Recreation New Zealand, 2005).

In the next chapter, the six research participants: Ben, Alehana, Isiah, Tariu, Davy and Paulo recall certain "feelings, thoughts and actions" (Maykut \& Morehouse, 1994: 126) playing 'Under-7s' for a local rugby club or running around a park with a 
rugby ball to playing rugby at the Westpac stadium for their college's First XV team, and, with the exception of Paulo, a Hurricanes secondary school team. 


\subsection{Findings}

Three sub-headings: (1) The early years, (2) Upper-primary, intermediate and earlysecondary school years and (3) Secondary school - the later years, are used in this chapter to provide a structure for presenting findings from the interviews with the research participants. Under each sub-heading a number of themes are discussed and together they provide insights into the growth of the research participants: physically, mentally and also emotionally. Many direct quotes by the research participants have been included to help expose their different personalities as well as their perspectives on a variety of matters; some to do with rugby and some not.

\subsection{The early years}

The early years of research participants' lives were characterised by exertion, family gatherings, beginning club rugby and starting school.

\section{i) The research participants' families and recollections about life at home}

The number of members, the gender balance and the make-up of each participant's family is quite varied. Isiah is an only child. Alehana is also an only child, and his parents have lived apart for some years. Ben and Davy are both the eldest and the only boys in their respective families. Ben has one younger sister while Davy has two. Paulo, like Tariu, comes from a slightly larger family. Paulo has four older sisters and Tariu has three older brothers and one younger sister.

During the research participants' early years, home life and school life was characterized by bouts of activity as the following quotes by Alehana and Davy illustrate:

I was always running around trying to find something to do and as soon as they made me sit down I got cross.

(Alehana)

I was out of it, I was nuts. I was hyperactive and stuff. At school I think I was close to being diagnosed with ADD.

(Davy)

Being around others older than themselves and playing sport with them was not an uncommon experience for the research as Isiah, Ben and Alehana explain: 
I was the little kid always running around. I got a lot of injuries but I kept going. I just loved getting out there and you know I just loved playing sport.

In the street there was a whole bunch of kids. They were a couple of years older than me. It was a quiet street and you could always have a game of cricket or whatever. I didn't feel like I wasn't one of them, like you know the little baby tagging along.

In those days I had older cousins and I loved trying to play around with them. ... There was always a rugby ball around and we would play anywhere, on the road, anywhere. I'd get bashed around every now and then but that was just the fun of it really.

(Alehana)

Tariu notes how he was "really mischievous" when playing around with his older brothers. Somehow they tolerated his actions and at the age of seven they gave him a place in the family basketball team. And Paulo remembers how after spending time at the local park, "playing with kids from across the road," he would spend time kicking a ball around his backyard and calling himself the names of famous rugby players that he had heard about.

Research shows that elite athletes tend to come from families where they had one or more siblings (Sport and Recreation New Zealand, 2004a). Certainly, the quotes above show the research participants prided themselves with their abilities during their early years to handle the 'rough and tough' environment that was part of playing games with boys older than themselves. Being 'bashed around' or occasionally injured during a back-yard game of 'touch' did not deter them.

In recommendations to coaches and managers, Howe (1990) encourages the pairing up of younger athletes with older more experienced athletes as one way to quickly and effectively improve the skill set of those in their charge. Without his older brother's help, Tariu believes that it might have taken him a couple of seasons before he could be proficient at tackling opposition players. Tariu recalls what happened after his older brother came to watch him play his third ever game of rugby - a game where Tariu failed to tackle his opposite or any of the other players when they had the ball.

He growled me off on the way home and then when we got home he just let me tackle him until I, until I, dropped him and then I knew what to do. 


\section{ii) Aptitude for playing rugby}

The age the research participants began playing junior club rugby varied from four to eleven years. Ben, Davy and Paulo all recall how on club days they "played across the field." 17 Tariu, who came from a "basketball family," and Alehana, whose mother had insisted he play soccer to "sort of ease me into the physical side of things," were aged ten and eight respectively before they began playing Saturday morning rugby. They played on a full sized field from the start. Isiah, who settled in New Zealand when he was eleven, began playing rugby almost the next day. $\mathrm{He}$ explains why:

You know, it [rugby] was the number one sport here so I tried it. And yeah, I liked it.

Shortly after the research participants began playing rugby, they became aware they had a talent for at least one aspect of the game. Ben, Davy, Isiah were able to accelerate quickly from a standing start. Tariu, Paulo and Alehana found that they enjoyed, even revelled in, the physicality of the game. The research participants, with the exception of Isiah and Ben, appear to have been above the norm in terms of height and weight, especially in their early years and during primary school. During these years rugby teams are graded by age, and size can be an advantage in more ways than one as following quotes illustrate:

I played rugby, tackle rugby at the park, that's the only time you could play tackle rugby because it was only touch rugby at the club. It was good. I was a good tackler from pretty much my early days. Even though I wasn't quite as big as I am now I was feared by a lot of the other bigger kids.

(Paulo)

I started on the wing and then moved gradually into the forwards at about age eleven. I had a bit of pace back then. I just got given the ball and no one would want to tackle me. I was quite big I guess when I was young and in rugby any kid that sees there's another big kid right next to him doesn't really tackle him. Thinking back, I guess you could say I was a bully.

(Alehana)

It is not my intention to debate, here or even later, the extent to which the research participants' achievements to date in rugby were the result of intense practice or innate abilities, but I note that Baker \& Horton (2004) and Ericson, (1996) are among those who strongly suggest excellence in sport is the result of intense practice rather than some form of natural ability. The majority of the research participants began

\footnotetext{
${ }^{17}$ A modification used in the junior grades as a full field can be very daunting for the young players. Across the field keeps the game manageable and both sides have more chances to score tries.
} 
playing rugby and attending practices at a reasonably early age. By the time Ben, Alehana, Tariu, Davy and Paulo were seventeen they had been training for close to ten full years, as they all undertook some training during the summer months although not always in rugby. As Ben pointed out, "on holiday there was always a ball."

\section{iii) Significant others}

The research participants all had fathers who had played rugby or, in the case of Davy's father, were still playing rugby. Tariu recounted how some friends told him about signing-in day at the local club just after he had been looking at some photos of his father playing rugby in Samoa. Then and there, he decided to broach the subject of playing rugby with his mother. His mother agreed to discuss the matter with others in the family and it was decided that Tariu should be taken to the park the following Saturday. Within a few months new routines were established to help Tariu in different ways:

It started off from there with those friends. ... When I was at college Dad always came to watch my games but when I was younger it was Mum and my older brother. I always had lots of family support. Yeah, Mum and Dad played a major role. ... When I came in from training Mum would have cooked dinner and then I could go and warm it up. ... And my brothers, they were always, always training me; making me do bodyworkouts, push-ups and sit- ups.

Ben and Paulo's fathers acted as parent-coaches in rugby and athletics respectively and both Ben and Paulo reported they were comfortable with this situation. This finding is similar to those reported by Barber, Sukhi \& White (1999) in their study into the effects of parent-coaches on their children's anxiety.

With Ben's father being "a bit of a rugby nut," Ben noted his mother had little choice about becoming very involved in following Ben's progress in the game. Working together they provided Ben with "huge support."

They were always taking me to and from training and helping with fund-raising for trips. Really what ever I needed.

Being "very cold" at games held early on a Saturday morning is one of Paulo's earliest memories. But Paulo knew there was little use moaning to his father. He elaborates: 
My old man's a big influence on me. He put us into a lot of sports. Sometimes we wouldn't want to go. We wouldn't want to get out of bed and go swimming but he would say, 'it's only one hour, you can do one hour.' He wouldn't force us, like he would just give us that motivation. ... At the end of the day I enjoyed that, the training and all that. I enjoyed it because it gave me a good work ethic.

In general, the mothers of the research did the shopping and cooking of food in the various research participants' households. Isiah's father was the exception:

My Mum was doing a lot of the shopping but my dad he sort of knew what to eat for a sports person. He sort of knew what I needed to have and he took over and had a pretty big say in the shopping.

Mothers also "found things," "washed clothes" and "brought boots" and while all the rugby players were grateful for their support Alehana positively sang out praise for his mother:

She is very passionate about her rugby but she is even more passionate about the fact that I play safely. What Mum hopes is that I do things smartly and learn the more technical aspects of the game. ... Every week, for every game it's my Mum that makes sure I'm ready, that I'm in $100 \%$ condition.

In addition, it appears that it was the rugby players' mothers who encouraged their sons to work well at school. Ben, Alehana, Isiah and Paulo all reported that their mothers were "very strict" or "quite strict" about doing homework.

In terms of support from other family members Tariu, Isiah, Paulo and Alehana all recall that they had an uncle who came into their lives for a period of time and helped them with motivation and advice. They also noted that on different occasions other family members, for example cousins, aunts and uncles, would attend games and cheer them on. Davy was the only rugby player to talk about active support from his grandparents. They bought food to the house and attended as many games as they could. This turned out to be nearly every game.

Those in a position of prestige and power consciously and unconsciously make and voice their judgments that influence the sport socialization process of young children (Hirschhorn \& Loughead, 2000; Kimiecik \& Horn, 1998; Stein et al., 1999). The parents of the research participants, with the possible exception of Isiah's parents, acted very much in accordance with the parental actions recorded by Coakley (1998); Côté et al. (2003); Côté and Hay (2002) and Stevenson (1999) in their respective 
studies; that is, they were the ones who in the first instance took responsibility for getting their children into organized sport of some kind.

Once in a sports team, the research found that those closest to them tended to react to their every move with positive delight. There was laughter all around when Davy took the ball out of the hands of a fellow team mate just before he was about to touch down, and again when Ben scored a try at the wrong end of the field after half time. Similar reactions were recorded by Brusted (1996) in his study into parent behaviour and participation in sport. As noted earlier, Stevenson (1999) uses the word 'entanglements' to describe relationships which act to involve an individual more and more deeply in an activity. It is likely that the relationships the research participants had with their parents and others during their early years playing rugby and the positive affirmations they received from these people greatly helped the boy's enthusiasm for not only getting to rugby but also striving to improve. Exposing just how 'entangled' the research became in their sport and how certain 'commitments,' which Stevenson (1999) suggests progress almost naturally from 'entanglements,' acted to keep them moving forward in their sport is covered in the next section of this chapter.

\subsection{Upper-primary, intermediate and early-secondary school years}

During these years, the research participants in the study found new friends among team-mates from their club rugby team and among fun teams, hastily put together at school for a variety of different sports tournaments. At times their enthusiasm for being involved in sport led to injuries of various kinds.

\section{i) Building on and consolidating skill}

During late primary and the intermediate school years there existed many opportunities for the research participants to not only continue playing rugby (or in the case of Isiah to start playing) and to also 'try their hand' at playing other forms of organised sport. Ben and Davy recollect:

I pretty much put my hand up for everything, yeah, netball, hockey whatever. ... Later I gave basketball, athletics, surfing, golf a go but l've never really had as much talent or whatever with other sports as I did in rugby. 
I played everything, I played cricket, basketball and did swimming so not just rugby ... Later I had a go at hockey, soccer, cricket (third eleven) and I can't remember the rest.

(Davy)

Isiah tried playing basketball at intermediate but because he found the opposition players were always "in your face" he did not enjoy the experience. At college, Isiah enjoyed his time playing volleyball and cricket but relatively quickly decided to put most of his effort into just one sport; athletics notwithstanding. Isiah never passed up an opportunity to trial for athletic tournaments and with his quick pace his selection was almost guaranteed. Alehana and Paulo's sporting experiences throughout intermediate and junior secondary school were wide and varied. Practice times for the different sports at Alehana's school were reviewed so he could run from one to another on any given day. Paulo was a competitive swimmer and took part in field athletics. ${ }^{18}$ In contrast to the other research participants, Tariu entered secondary school with the idea that he would "stick with one sport." His brothers had told him this was his best option if he wanted to "go all the way" in rugby. However, feeling he should contribute to helping the school's athletics team Tariu began training for the shot put. A stress fracture sustained a short time later convinced him his brothers had been right after all.

Isiah and Ben said they were very surprised to make it into a regional representative rugby team just before entering secondary school. Meanwhile, Davy, Alehana and Tariu were expecting to be named in their respective regional representative teams as they had been actively working towards this particular milestone for some time. Davy's story about what he did to gain a place in one particular team is illustrative of his willingness to do what it took to achieve a goal:

The Hawkes Bay has this thing called the "Ross Shield." Only those under $53 \mathrm{kgs}$ can play, and so I had to lose something like $12 \mathrm{~kg}$ to make that team. I pretty much went on a drastic diet, sauna room and really big stuff and yeah I lost it. It pretty much turned me into a back because I lost so much weight. ... It was big. ... Back then it was everything.

The decision by each participant to make rugby their sport happened at different times, but in general terms this decision had been a made by the time the boys were aged twelve. The point at which the decision was made indicates the start of the

\footnotetext{
${ }^{18}$ Paulo won titles at regional and national level and at the Pacific Schools Games in Australia. In Sixth Form Paulo took up rowing and became a national secondary schools champion.
} 
“specialising years” (Côté et al., 2003; Côté \& Hay, 2002). Increasingly, the research participants worked hard to make particular rugby teams, but yet their motivation or task orientation was largely intrinsic as opposed to extrinsic (Allison et al., 2005; Weiss \& Ferrer-Cajae, 2002). Again, it is possible that at this time the motivation the research participants had for playing sport and rugby in particular was connected to the very positive responses they continued to get from parents and others (Bloom, 1985; Brustad, 1996; Kimiecik \& Horn, 1998; Stein et al., 1999). Even if this were not the case, it is very evident that as a group the research participants entered adolescence with well-developed athletic skills. Doubts about competence (Fredricks et al., 2001; Smith, 1998 and Weiss \& Ferrer-Cajae, 2002) were not an issue for these young men. Lastly, and very importantly in terms of gaining status, playing rugby, basketball and volleyball were all sports that were valued by their peer group (Allison et al., 2005; Fredricks et al., 2001; Light \& Kirk, 2000; MacPhail and Kirk, 2006).

\section{ii) Selecting a secondary school and initial impressions}

Following Ministry of Education policy, public schools throughout New Zealand must take students from within their zone. However, many popular schools and all private or integrated ${ }^{19}$ schools operate an enrolment scheme as well to ensure they can offer some places to out of zone students who may have a particular reason for wanting their child to attend a particular school. Because of where they lived, Ben's parents could effectively choose between sending him to a traditional boys-only college or a large co-educational college. After consulting Ben they chose the traditional boys college. Paulo and Isiah also attended this college despite living outside the school's 'zone.' Paulo's words:

It was my Mum's decision. She was on to me, I don't know, she wanted me to, she wanted to give me a better chance. I don't know, greater education and play sports and that. Her brother and third cousin went to the school so it was a bit of a family thing as well.

At some point in his Third Form year Isiah's family moved closer to the college. Isiah was very happy about the move as he was finding the train and bus trips into and from school each day very time consuming. Tariu also attended a traditional boys-only college well away from his home. While it was an integrated college and

\footnotetext{
${ }^{19}$ An integrated school is a special character school, often a religious-based school, with teacher salaries funded by the state.
} 
he had a cousin who taught there Tariu had two other reasons for wanting to attend this school:

I wanted to get away from my brother. He is two years older than me and I wanted to be in my own environment and yeah, also the rugby there was good.

Davy too travelled a considerable distance to his first college. The school was the only integrated college in the region and it was a given that boys from the Catholic primary schools thereabouts would attend this college. The college had a reputation for being able to field several competitive rugby teams at the start of each new rugby season. Meantime, Alehana attended, initially as a day pupil and later as a boarder, the college attached to the preparatory school to which he had previously won a scholarship at the age of nine.

Jackson and Bissett (2005) found past academic achievement and certain values, of either a secular or religious nature, to be the foremost factors parents considered when faced with choosing a secondary school for their son. 'Sporting achievement' was rated another key factor influencing their decision. Tariu, Davy, Paulo and for a short time Isiah, travelled a significant distance to their colleges at considerable cost but used their time on the buses and trains to talk about rugby, school, food and girls. When Ben had practices after school he would often meet his father in town and get a lift home with him.

Within a very short time of arriving at their respective colleges, if not before, all the research participants had decided that making their colleges' First XV team would be their big goal. Paulo, Davy and Ben describe how it was for them:

It [the First XV] was a big thing at school, it was like a mythical team to play for. That was like the highest you could be, and once you make that you're looked up to by all your peers. So you know from Third Form watching the game, the 'traditionals', you look and see and you know you want to be out there. You wanted to be out there when you grew up so yeah definitely, definitely a goal.

(Paulo)

Oh yeah I had a dream of being in the 'Firsts'. When you are first at a school and you sort of enjoy your rugby then that's sort of your main goal. The first thing you want to achieve is to make the First XV but it just looks so impossible. You look at the size of the people who are in there and you are just a little Third Former and just crazy.

(Davy)

Oh I made that [making the First XV] pretty much as a long-term goal pretty much from day one. Yeah, because like at school when you get there, they like have the traditional games, which they play on the Wednesday afternoon and the whole school 
used to watch them, and I remember thinking, that's going to be me one day I hope.

(Ben)

In most colleges making the 'Under- $15 \mathrm{~s}$ ' is seen as a necessary step on the way to making the First XV rugby team. Alehana, Tariu, Davy and Isiah were named in their respective colleges' Under-15 team in their Third Form year. Paulo and Ben were named in their college's Under-15 team in their Fourth and Fifth Form years respectively. For Isiah, this team was everything he thought it would be and more.

In my first year at college, we had an Under-15 tournament up in Auckland, and it was sort of my first travelling like for rugby and I thought it was awesome. We went up on the train and we stayed in a hotel and coming from Samoa you know I was just not really used to it. And I thought 'wow this is good.' It kind of hit me, it was like 'wow this is, this is great.' You know travelling, finding out parts of New Zealand. I was in Auckland, l'd never been to Auckland before. And staying in a hotel and everything's cooked for you. It was like 'wow this is awesome.' That was sort of my first experience of rugby, I thought 'wow you know I'm liking this.'

All the research participants spoke of very visible, male-focused traditions at the colleges they attended and were keen to talk about past pupils who were making a mark in their chosen sport. Tariu was particularly keen to talk about one of the present All Blacks who had been a senior pupil at his college the year he started there. The traditions described were similar to those described by Lashlie (2005). She interpreted these traditions as being, "about connection, about linkages to the past, that show pathways to the future and it's about excellence, striving to be successful in order to honour those who have gone before" (Lashlie, 2005: 37). In this light Davy's switch to another school at the start of his Sixth Form is problematic. Despite being fully involved in a number of sports he followed his "best mate" to a different school.

Peer pressure of kind discussed by Fredrick's et al. (2001), Smith (1998), Messner (1990) may have played a part in Davy's decision. However, other factors suggest Mac an Ghaill's (1996) idea that individuals act in ways that correspond to whatever identity the individual is constructing for him or her self is a more likely reason. The First XV team at Davy's new school was very highly ranked in the country, not just the region, and his friend had informed him that the coaches were "awesome." According to Stevenson (1999), manoeuvring themselves into environments that help their bigger cause is a common practice among athletes that ultimately 'make it.' 


\section{iii) Injuries}

At different times during their junior secondary school years, three of the research participants had to work at overcoming one or more physical injuries. Tariu's stress fracture, sustained shortly after arriving at college, was noted earlier. He describes how he treated this injury:

The stress fracture was a bit of a scare because I was supposed to be out for six months but a week after l'd seen my doctor I went to a training camp. I just carried through with the pain, and then I just started taking some nono juice from Samoa and I don't know if that helped but it got better after that.

Damage to Tariu's acromio-clavicular (AC) joint, suffered while training with members of the First XV team who were generally a lot bigger than he was at the time, resulted in some changes at his school. Greater supervision during lunch-time training sessions was put in place and a gym instructor from a commercial gym was bought in to instruct the boys on the correct use of gym equipment. Tariu was put under the care of a local physiotherapist.

Davy explains how on two different occasions he became injured and what he did to recuperate:

I had damage to my lower vertebrae. It was not from rugby but it ruined me for rugby for a while. I would have to take short breaks all the time. I was trying to bowl really fast and that put a lot of stress on my back. And then another one I did was the medial ligaments in my knee. ... My uncle was a physio and he was looking after me. I really wanted to play and then l'd get hurt and he was giving me treatment and I did some swimming and it eventually came right.

A fractured ankle suffered during Isiah's first training session with his college's First $\mathrm{XV}$ team nearly derailed his rugby playing plans. He explains how it happened:

I fractured my ankle towards the end of Fourth Form. I was playing with the older guys, who were more mature and their bones are different. Yeah, so I was at training and I kicked and I tripped and I fractured my ankle. Lucky, luckily it was the end of the season so I had that whole time to come back and prepare for the following year. Then I played First XV in the Fifth Form. ... At the start you know I had to [start] like gradually, like with my fitness because getting my fitness back was at the top, big time and yes hard for me. ... When I came back, our coach, he manages some famous players and [he] sort of told me to go to physio because I had no idea what a physio was.

The musings of Tariu, Isiah and Davy with regard to their attitude to dealing with injuries is not dissimilar to the musings of the football players in the Foley (1990a; 1990b) study and the rugby players in the Light and Kirk (2006) study. 
Stevenson (1999), in his investigation into the careers of members of British and Canadian national teams, contends that over time aspiring athletes build up a set of obligations to different parties, for example their coach and manager. These sets of obligations act to tie the athletes to their sport. Even when obligations to certain parties, for example parents and past coaches, are largely imagined they can remain a potent force. Furthermore, obligations to team-mates can come to mean showing “appropriate attitudes and behaviours" (Stevenson, 1999: 92). It is highly likely that obligations, to coaches, parents and/or team-mates, were considered by Tariu, Davy and Isiah when they were making respective decisions about whether to continue playing rugby while carrying, or recovering from, serious injury.

\subsection{Secondary school - the later years}

Entering the senior years at secondary school meant the research participants had to change their focus from general study to studying towards national examinations at the end of the academic year. Playing First XV rugby was now a reality and having to uphold the pride of the school at 'traditionals' was a big responsibility. In addition, the research participants were starting to look ahead and think about what they might do when they left college.

\section{i) Balancing differing demands}

At the start of each school year, it is not unusual to find secondary school principals, deans and form teachers encouraging their charges to take time to think about and write down their goals for the year. As already noted, making their college's First $\mathrm{XV}$ team was a key goal for the majority of the research participants, from the time they first set foot in their college, if not before. Three of the six research participants took time to write this goal somewhere and Davy drew pictures of the jerseys of all the teams, including the All Blacks, he had set his mind to play in. He pinned the pictures to his wall as a visual reminder of where he was heading with his sport. However, when the research participants were actually named in their college's First $\mathrm{XV}$ team they found they had another challenge to overcome - specifically, how to juggle the demands of school, friends and, at times, family with new, intense, timeconsuming training schedules and build-ups to games. 
The research participants dealt with this challenge in different ways. For Davy, academic study took "a bit of a back seat" when he was named in the First XV team. He explains why:

When you get in the First XV at a young age it goes to your head, yeah well it went to my head and sort of sat there. And then I was, 'oh I don't need to do School C, I'm in the First XV' and stuff. Yeah, I was just your average arrogant Fifth Former in the First XV.

Upon finding themselves in their college's First XV team, and in contrast to Davy, Tariu and Ben kept on pouring effort into their studies. They explain how it was for them:

Early on I learnt to respect the fact that I was on a special team. I didn't try to abuse the privileges I did have. I just kept working, yep, homework, practice, school. ... It was busy; Monday, Monday we were at training, Tuesday school training, Wednesday rep training, Thursday school training. And then in my holidays I had my New Zealand side, yeah and that just flowed through from Fourth Form straight through. ... On Sundays l'd go to church and just hang out with the family, yes. Then back into it.

(Tariu)

Finding time [for everything] was pretty tough and yeah I remember, especially I think it was in the Fifth Form, when I had 'Under-16s' and yeah, we had two school trainings and two rep trainings a week plus yeah trying to fit in homework. Sometimes it meant some quite late nights if you had assignments due and stuff and then you had to get up for training at seven. It was pretty tough in those days.

(Ben)

Alehana feels he was both "lucky" and "helped" by the fact that his school "wasn't that great at rugby."

School was the main thing; I was just caught up in that kind of atmosphere. ... If you think about it you never know if you're one game away from breaking a leg or having a serious injury and never being able to play again. There's a lot of people who have one injury that puts them out for good and now they're just standing on the doors, doing door work. But I wanted to have some options.

Davy's realisation, near the end of his Fifth Form that he needed to actually apply himself to doing some form of study over and above homework exercises helped him to pass some School Certificate subjects. However, Davy recalls that by Seventh Form although he attended classes it was "rugby all the time." Similarly, Paulo and Isiah's commitment to academic study "slipped away" after they also passed School Certificate. Yet, interestingly all three students had at least one teacher they could turn to for help if they got themselves in some bother with the office staff or even another teacher. Davy noted he had two teachers who would "kinda sooth the way" when he forgot, or more usually failed, to hand in assignments. At other times, these 
teachers would remind him to follow procedure or keep a low profile so as not to attract undue attention to himself.

All the research participants regarded their five years at secondary school as "special," "great" or "the best." Such sentiment, especially from those whose academic success at college was limited, appears to endorse Coakley's (1998), McNeal's (1995, cited in Coakley, 1998) and Marsh's (1993, cited in Coakley, 1998) assertions that adolescent involvement in a sport, or sports, helps to ensure a strong and lasting identification with the organising institution.

\section{ii) Consolidating reputation and constructing identity}

The aspiring athlete, having negotiating his or her way through the entanglement, and commitment stages (Stevenson, 1999) or the sampling and specialising stages (Côté et al., 2003; Côté \& Hay, 2002), reaches a point when he or she must make certain decisions about his or her further involvement in a sport. An individual athlete's own evaluation of his or her relative potential for success which the sport being considered offers is probably the area given the greatest attention (Stevenson, 1999). Sporting success greatly helps those wishing to identify themselves as having a sporting identity although the actions of peers, parents and others can also contribute to how the athlete is perceived by the community he or she moves in (Stevenson, 1999). Regardless of how a certain sporting reputation is gained, the effect for the individual concerned is the same. That is, he or she is reassured that any decisions made at some earlier time to continue involvement in a particular sport were not made in vain.

This is important because when each of the research participants became a member of a First XV team he effectively confirmed to his peers, family and also himself the long-held belief that he had a talent for the game of rugby (Brustad, 1996; Kimiecik \& Horn, 1998). Each time he was selected to be part of a prestigious representative rugby team, the profile of the players within their school, local rugby clubs and communities was further enhanced. Indeed, as each rugby season progressed, the idea that he was considered to be a player 'to watch' was not lost on the participant.

The fact that all the research participants experienced nerves and showed signs of anxiety before playing a First XV team from another college can be explained by 
noting the level of importance various boys schools attach to winning the traditional fixtures (Lashlie, 2005; Light \& Kirk, 2000) and needing to gain points in the current season's competition. The nerves and anxiety can also be explained by the research participants knowing that their emerging identity would be at stake from the time they first touched the ball until the game was complete. Isiah elaborates on how it was for him in the period before an important game.

I always get nervous like before a rugby game, I don't know why. It's like, you know, you're trying to tell yourself it's just another game of rugby but, I don't know, maybe it's a human nature thing. I work on trying to settle myself down and give myself a talk. That's what I do.

Both Davy and Tariu made use of visualizing techniques to help them focus on the job they were about to do but Davy later added that he didn't ever do this for long, preferring instead to "walk around and have a bit of sing," and to "to laugh and talk to guys." Meantime, Alehana's approach was a little more philosophical:

At college I got tense but, 'cause [I] got told by various people I could be a great rugby player I just tried to stay true to that. ... I had people who helped, people around to keep me sane. And Mum - Mum kept me strong.

Playing First XV rugby gave the research participants the opportunity to play at least one game each season at a major sporting venue near their school. All the research participants noted that they used these occasions to keep alive their dreams of going further with their rugby. Paulo's recount of what it was like playing rugby at the Westpac Stadium in Wellington was a little more detailed than the stories told by the other research participants but the sentiment was the same.

You know, just the ground and the atmosphere. That was the main thing I think, just to be there and see that one day you could be here, in a Wellington jersey or an All Black jersey, with 30,000 people screaming your name. Awesome, really awesome experience.

As members of the Hurricanes Secondary Schools Team in their final year at college (Ben, Alehana, Isiah, Tariu and Davy) and the New Zealand Under-16 team, the New Zealand Under-17 team and the New Zealand Under-18 team (Alehana, Isiah and Tariu) there were further opportunities to play at the Westpac Stadium. For Alehana, the experience of being in one team helped consolidate the identity he had been actively constructing for ten, possibly eleven, years:

When I hit the New Zealand Under-17s that's when they started letting us see what the future could be. You know, they put up role models and all that, and they told us what they had done to get where they were, what they were earning, that kind of thing. And 
they would tell you that they were sitting in the exact seat that you are in now. Yes, they showed you the path forward.

\section{iii) Relationships and role models}

Many of the relationships the research participants formed during their senior years at their respective schools were dominated by the fact they were members of their college's First XV team. The expectation that they would be available for meetings, gym sessions and practices at set times each week, and the goals the research participants had set for themselves, left little time for meeting others outside the First XV camp. This situation did not appear to have greatly perturbed the research participants and endorses the idea that enjoying being with people who are involved in and around an athlete's chosen sport contributes significantly to decisions made by adolescents about whether to move forward in his or her sport (Brustad, 1996; Coakley, 1998; Stephenson, 1999; Allison et al. 2005). Not only did the research participants develop strong bonds with different members of their First XV team, some, like Isiah, also developed strong bonds with members of other teams they met on a reasonably regular basis.

Yeah, I'm thinking you know $X$ [another of the research participants] Well I sort of played against him since I was about thirteen and then we've been making the same rep teams together for um yeah, a long time. So we are pretty tight.

Going to 'rugby' parties on Saturday nights were not uncommon occurrences for the research participants during their senior years at secondary school. However, the following quotes illustrate that while the research participants attended a lot of parties they tended to act in quite a restrained manner:

I'd go with a couple of friends who I knew didn't drink and we just sort of walked around and held our own. We'd be seen and then we would go.

(Alehana)

I'd go out to parties with the boys but you know I don't do alcohol 'cause I'm thinking about my body. Yeah, like some guys they don't, they sleep all Sunday and by Monday they've not trained their body.

In my last two years most weekends I acted as the sober driver for my mates 'cause a lot of the time l'd have something on Sunday, yeah.

Davy appears to be the exception in terms of the crowd he socialised with and the amount of alcohol he consumed:

Well, it was like I sort of hung out with guys that were a bit older than me. One in particular was, you know quite a good cricketer and so he always had a fair bit of money with him. Not that I abused that, but there was lots of drink. ... Actually, I didn't 
start drinking until I was seventeen. I held off for quite a long time. Looking at it now I probably should have kept holding off.

Only one participant admitted having a girlfriend during his senior years at secondary school but noted that "it was only for a short time."

By the time the research participants were in their Seventh Form year they each had at least one adult, outside of their family, working along side them to ensure each of them were well prepared to play rugby to their potential each week. For some players the relationship between the adult mentor and themselves had begun two or three years earlier when the player concerned was fourteen or fifteen. Tariu, Alehana and Isiah had one of their previous, First XV teacher/coaches continue as their mentor throughout their time at their respective secondary schools. Ben and Davy had support from the teacher/coach of their Sixth and Seventh Form First XV team and Paulo had his athletics coach from his athletics club looking out for him in different ways. The following quotes are illustrative of how two such relationships developed:

Like I had Mr Y, he came [to our school] when I was about Fourth Form and he took me under his wing and made sure that I was alright because he knew that Mum was sort of struggling along at home. You know family can be a broad concept and we consider him part of the family.

(Alehana)

$\mathrm{He}, \mathrm{Mr} \mathrm{X}$ had been our coach, but for me he was more than a coach. He helped me with like everything, he told me what to do. He used to play second five and he gave me ideas.

The part that these persons played in the participant's lives was one of regular encouragement and guidance, especially with regard to options available to the research participants once they left secondary school (Coakley, 1998; Coleman \& Hendry, 1990; Fergusson et al. 1994). In addition, they also provided support for the identity that each of the research participants was in the process of developing and maintaining (Mac an Ghaill, 1996; Stevenson, 1999; Swain, 2000; 2002).

As noted earlier, for male adolescents, role overload, certain structural determinants and negativity from peers and family can act as barriers to participation in sport (Allison et al., 2005). In almost stark contrast, narratives related by each of the research participants appear to emphasise people who worked with them to minimise role overload or mollify structural problems such as lack of transport, specialised knowledge or funds to do certain activities. In addition to one or both parents being 
present at nearly every one of the research participants' games, Davy, Tariu, Isiah and Alehana had uncles and cousins and occasionally grand-parents who made every effort to get to as many games as they could each season. Lastly, the boys themselves were adept at finding ways to "keep in" with their peers. Alehana articulates one reason for having good mates around.

Sometimes like l'd be stressing out over all these things but luckily I had friends who I could talk to and remind me again that life's not just about rugby. ... They sort of keep you sane. Yep.

Then again, dreaming about playing rugby at a very high level was used by each participant as a powerful motivating factor at various times; from around the age each participant began playing rugby until the present day. More specifically, adopting a past or present All Black, Super Twelve (now Super Fourteen) player, champion sports person or civil leader as a model for what can be achieved was something each participant did at some point during his time at secondary school. While Alehana and Paulo each had four different role models to pick and choose from, Tariu and Ben only had one:

I admire Michael Jordan. Even when I'm playing rugby it is always Michael Jordan. ... I like everything he does, his style, the way he plays, everything it is not just about basketball.

(Tariu)

Yeah, I always watched Josh Kronfield. He was pretty cool. He was an awesome player and also off the park as well; he was a pretty laid back sort of [guy], a really good guy.

In addition to role models being used as examples of achievement through hard work and determination, role models were also used as confirmation that the path the research participants were on was not unique. Indeed, it is possible that identifying with particular persons may have provided the research participants with a sense of belonging to a special community of sorts; perhaps the community of winners. 


\section{Summary}

This study sought to 'paint a picture' or document the life experiences of six young men who played First XV rugby for their college. This chapter is the result and it shows that after gaining a place in their college's First XV team the majority of the research participants moved on to gain even higher honours. In addition, this chapter provides insights into the research participants' family life, school culture as well as life after school and on weekends. Friends, coaches, mentors and others were mentioned as the research participants reflected on their lives to date. In the next and final chapter the focus is on individual agency and how further examination of the data collected reveals much about the character of the research participants. 


\subsection{Discussion and Conclusion}

Much of the information in the previous chapter resembles information typically found in a variety of print media about up-and-coming and leading rugby players. For rugby aficionados, and even people newly introduced to the game, biographical information, such as where the rugby player was born, his parents' occupation and the schools he attended, can provide ammunition for their particular theories about how a person gets to play first-class rugby in New Zealand, why one player and not another was selected for a particular tour or why some players have developed specific abilities that make them legends in their own lifetime. The discussion below adds some clarity to these ongoing debates and provides knowledge about strategies that can be used to gain success in sport and in any number of other endeavours.

Linking promise to the podium, referred to in Chapter 2, is an informative report about gaining high honours in sport in the New Zealand context and about talent development. The foremost conclusions that emerged from this report are listed as: (1) there is no simple way to accurately identify future talent in sport, as talent is dynamic and multi-dimensional and can emerge at any point during an athlete's development, (2) environment, genetics, mental ability, physiology and support are all key elements to developing talent and (3) environment is the easiest element to manipulate to increase the chances of an athlete fulfilling his or her potential (Sport and Recreation New Zealand, 2004a).

This research project strongly endorses these three findings. From a young age the young men in this project enjoyed playing games outside the house and they became excited whenever they had the chance to participate in sport of any kind. As they grew they experimented with finding the limitations of their physical abilities, all the time enjoying the sensation of movement across the different planes. It is not possible to pin-point an exact time when each research participants' talent for rugby actually emerged. However, being selected for certain rugby teams confirmed the research participants' feelings that they had certain abilities that with practice would further develop and make them into players that would be noticed. 
The nature of the research participants' genetic make-up was not fully explored in the data collection phase of the research but clearly there is something in their individual mix of genes that helped them make a claim for a particular position on the field. Also their individual mix of psychological traits has impacted strongly on their ability to be able to 'push on' towards particular goals or have an advantage over other contenders. Even without the aid of testing the research participants' levels of intelligence, I assert that well-developed language skills and good levels of general intelligence played a part in developing their talent. The research participants' homes, their junior rugby clubs and their schools all fostered their talent and at times promoted it so that the young men could start to really believe in their abilities and move to the next level. Family members supported the research participants' involvement in sport, and when they were really pushing to make particular teams other people came into their lives and nurtured them in a variety of ways.

Thus, I contend that key elements with regards to developing talent were present in the research participants' lives. But the data also reveals that individual agency, or specific actions taken by an individual, played a significant role in helping the research participants secure a place in their colleges' First XV teams. The research participants described their actions, and also reactions to events, almost unwittingly as they answered questions about home and school life, going to training and playing particular games of rugby. Six characteristics have emerged from an analysis of the research participants' actions (and reactions) and they are: (1) awareness that rugby can be a career for only a select few, (2) responsiveness to coaching, (3) ability to set and work towards a long-term goal or goals, (4) decisiveness and an ability to prioritise, (5) valuing the input of others and (6) attractiveness.

In emphasising these characteristics I am not advocating that only those with these characteristics or those undertaking a certain range of actions can gain a place in a secondary school First XV team or any other prestigious sports team. This thesis remains a study of six young men who attained elite or sub-elite status in rugby while studying at a secondary school in New Zealand. Indeed, not all the research participants displayed the characteristics listed above to the same extent and some only displayed the full set of characteristics after they had been exposed to their particular college's First XV culture for a period of time. 
In singling out the display of certain characteristics and describing each one in detail below I do not ignore the fact that other factors almost certainly helped the individual research participants develop their rugby skills, be noticed and move forward. These include playing a range of sports when they were young, being mastery orientated and being exposed to good coaching.

\section{Awareness that rugby can be a career for only a select few}

All the research participants, with the possible exception of Isiah, were well aware of the All Blacks and their status in New Zealand from an early age. When rugby in New Zealand became professional in 1996 the research participants were aged ten, eleven or twelve and they were quick to follow the new Super Twelve competition. It was around this time that Alehana, Tariu, Ben, and Paulo appear to have become aware of the range of skills top rugby players displayed and decided they could work on developing similar skills by spending more time outside playing with a rugby ball. They actively sought out older brothers, friends and cousins for a game of touch or joined in such games at the local park. Isiah did the same when he settled in New Zealand. But because they were aware that rugby can be a career for only a select few Alehana, Tariu and Ben kept their options open by ensuring they left college with sound academic qualifications.

\section{Responsiveness to coaching}

This trait emerged from the research participants' desire to improve their general skills and positional skills, so they would get selected for a particular team. While Ben and Isiah were somewhat surprised to find that they had been selected for the Under-12 regional representative rugby team, Alehana, Tariu, and Davy had been taking on board everything their coaches said and would have been very disappointed if they had not been named for this particular team. Problems, which could have been deterrents to some, for example forgetting to pack rugby gear for after-school practices (Isiah and Paulo) or having to catch two buses and a train home after practice in June when it is dark and cold (Tariu and Paulo) did not dampen their enthusiasm for learning new skills. When Paulo's father took him to the gym where he worked, Paulo revelled in following the training regime his father worked out for him. Davy and Ben also took advice from their fathers, and the other research 
participants appear to have welcomed tips and reminders from brothers, uncles and others.

\section{$\underline{\text { Ability to set and work towards a long-term goal or goals }}$}

Working hard to be selected for certain teams and being prepared to go the extra mile has been mentioned already. From early in their time at secondary school Ben, Isiah and Paulo focused on making their college's First XV team. This focus meant the research participants spent their time differently from their peers. Watching television and playing computer games were not rated highly by the research participants an an time in their lives. Going to movies and parties, having Sunday sleeps and a special girl took a back seat, with the exception of Davy. Throughout the entire time Tariu was at secondary school he only once went away on holiday with his family, due to training camps or travelling with various teams. There is a high probability that this was the case for Alehana as well.

Not everything the research participants prepared for actually eventuated. Ben ended up in the Under- $65 \mathrm{~kg}$ B team, not the A team. Paulo had to play second XV rugby for longer than he anticipated. But, these boys did not give up their dream rather, they sought advice from different coaches and trainers and worked on preparing themselves well for every game they played. Tariu, Isiah and Davy acted in a similar manner when coming back from suffering major injuries shortly after gaining a place in their respective college's First XV team. Isiah spoke of going to the park, at times when he was confident no one else would be around, to practise certain moves and try out different ways of kicking the ball because his old technique hurt his newlymended ankle.

\section{Decisiveness and an ability to prioritise}

Stevenson's (1999) observation that the processes of entanglements, commitments, reputations and identities act to draw athletes into having an athletic role identity is upheld by the data collected for this study. Over the course of their time at secondary school a whole series of "self-conscious and self-reflective decisions" (Stevenson, 1999: 94) strengthened the research participants' rugby-player identities. To further enhance their rugby-player identity, certain perceived weaknesses to do with their physical strength and appearance were worked on. By the time they were fifteen, all 
the research participants found their ways to commercial gyms (with the exception of Paulo who used his father's work gym). There they built up muscle power and enlarged their physiques. Ben, always conscious that being very fit at the start of the rugby season would give him an advantage over others who relied on team training sessions, didn't need his father's prompts to stick to the different training plans he had made out for himself at the start of each summer. The research participants' selection into representative teams, including their college's First XV teams, reinforced their rugby-player identity.

However, Alehana, Tariu and Ben managed to do something else as well. They were able to earn themselves reputations as capable students without letting their reputation as top sports people suffer in any way. They became adept at managing the very different demands of each endeavour. While their main friends were other rugby players they also valued the friendships they formed with their peers whose identities were aligned with that of scholar, or to put it more colloquially 'hard out'.

\section{Valuing the input of others}

With the exception of Alehana, the research participants chose their secondary school with some regard to the value put on sport in general, and rugby in particular, by the college. During their first year at their college, the research participants were quick to enlist older students or teachers to help them understand the formal and informal systems through which students find a way into particular sports teams. Tariu, with his cousin teaching at his college, had a particularly good start, but the others appear to have intuitively understood the power of social networking. Yet, as Davy was to find out, having a good relationship with one or two staff members does not necessarily stop a student developing a reputation for being disruptive. There was potential for Paulo to develop a similar reputation but he worked out some strategies for keeping onside with teachers and deans, for example getting his sisters to help him complete homework. Avoiding detentions also meant more time to experiment with a range of different sports. Over time, Paulo became an extraordinarily valuable sports person to his college, and by then a much more mature young man.

The actual methods that the research participants used to find themselves at least one person, outside their immediate family to mentor them and look out for them are not 
actually known, but it is likely a degree of politeness and positiveness played a part. Alehana and Tariu had their mentors in place by the end of the Fifth Form and the others, even Davy, by the end of their Sixth Form year. The various mentors appear to have helped the research participants change their diet, rest well before big games and employ techniques such as visualising and meditation before going on to the field.

\section{$\underline{\text { Attractiveness }}$}

Where the previous five characteristics link in some way to one or more of Gould et al.'s $(2001 ; 2002)$ list of characteristics common to elite athletes, as set out in Chapter 2, attractiveness does not. Neither is it listed in various researchers' lists of characteristics of ultra-successful people (Pickworth \& Moine, 1991). The reason for its omission is possibly because to acknowledge attractiveness is to invite accusations of shallow thinking, missing the point or even having been manipulated. Yet attractiveness can count, and does count, when wanting people to go out of their way to help. Moreover, the attractiveness I am talking about has little to do with physicality.

When the research participants related stories about their lives they showed a lot of humility when talking about specific achievements. They also showed that they had an overwhelming sense of gratitude to all people, especially teachers, who had helped them along the way. Other traits that can come under the heading of attractiveness include politeness, positiveness, generosity, reliability, steadiness, friendliness or connectedness, diligence and sensitivity to humour. These traits are ones that tend to be appreciated by teachers in general, and when present in students help greatly in establishing good working relationships. In all probability, a degree of attractiveness helped Davy and Isiah find a place in the school they wanted to attend and they almost certainly helped Alehana, Tariu and Ben gain the captaincy of their First XV teams in their final year at college.

Creating a list of characteristics or qualities common to the six research participants was not the original intent of this project. However, it has arisen from using the constant comparative method (Glaser and Strauss, 1967; Lincoln and Guba, 1985, cited in Maykut \& Morehouse, 1994) approach to analysing the data collected. The six characteristics listed above are by no means unique to the six research participants, 
but it appears the research participants practised and displayed combinations of these six characteristics at crucial times and in so doing boosted their chances of becoming a member of a secondary school First XV team and, with the exception of Paulo, other prestigious teams. One particular environment that all the research participants experienced during their adolescent years, that of a boys-only secondary school, has not been discounted as being highly instrumental in the participants acquiring the six characteristics.

Stevenson's (1999) idea that an interactionist theoretical perspective, as opposed to a socialization theoretical perspective, is useful for understanding why some athletes and not others make it in sport has been endorsed by this study. Findings in this study also support Allison et al.'s (2005) argument that adolescent males give up in sport after making an analysis of costs to possible benefits and concluding that the costs are too great. None of the research participants had to contend with juggling part-time work and by and large they were not subjected to unrelenting pressure from parents to achieve highly in certain subjects at school. Also, distractions in the form of girlfriends were circumvented by various means. One other aspect of Allison et al.'s (2005) argument that structural determinants, namely travel and costs, hinder adolescent males' participation in sport was not endorsed by the evidence presented in the in Chapter 4.

There are some limitations regarding this research project. They include: the size of the research sample, an absence of a comparative research sample of young men who had been noted as talented rugby players but had 'dropped out' of playing competitive rugby, and the absence of follow-up interviews with the research participants. A larger research sample may have generated more data or given more validity to the conclusions. A second research sample containing young men who have moved away from rugby may have rendered more detailed information on the influence of school and home environments on the emergence of talent in rugby. Lastly, having available material from one or more follow-up interviews could have led to the list of qualities, that can contribute to a young man being selected for his college's First XV team, being listed on a continuum from 'of least importance' to 'of great importance.' 


\subsection{Future research}

Parts of the stories told by research participants are very consistent with ideas put forward by key researchers writing about adolescents gaining excellence in sport. In particular I refer to the following ideas: (1) variable practice of newly learnt motor skills can lead to high retention (Heitman et al. 2005), (2) perceived competence playing a major role when adolescents are making decisions about whether they should continue to be involved in a sport (Fredricks et al., 2001; Heitman et al., 2005; Weiss \& FerrerCajae, 2002) and (3) expert levels in sport can only be reached after approximately a ten year involvement (Baker et al., 2003). Further, raw data collected during the interviews with the research participants resonates to a certain extent with the Gould et al.'s $(2001 ; 2002)$ findings about psychological characteristics found to be common to elite athletes. This is exciting and may provide starting positions for anyone wishing to explore ways to build depth in secondary school rugby. Other areas for study arising from the research findings are detailed below.

The number of injuries the research participants had was reasonably alarming. A research project that looks at the number of injuries sustained while playing schoolboy rugby, along with injuries that have occurred at supervised and unsupervised training sessions, may help alleviate the high rate of injury. Finding out more about how often male adolescents attend commercial gyms and whether they predominantly learn to use the equipment by following advice given to them from friends could be incorporated into the project.

I have noted that the NZRFU has a particularly good section on its website outlining different injuries rugby players can sustain and giving advice on prevention and ways to treat these. Presumably this section was included because the NZRFU is already concerned about injury and wants information about injury prevention and best practice for treatment to be available to all those involved in rugby. It would be interesting to know the level of awareness coaches and managers of junior rugby teams and parents of young rugby players have about this on-line resource. Certainly I know that some teachers of Physical Education classes in secondary schools are not aware of its existence.

It is also likely that the NZRFU have over recent years became aware of stories about secondary school aged rugby players and club rugby players who have little or, in 
some cases, no idea about the benefits that can be obtained by having a physiotherapist assess an injury. Consequently, it is pleasing to see NZRFU on-line resource actively promoting the use of physiotherapists for assessing injury and for advice on prevention of further injury. I note here that the government recently passed legislation enabling physiotherapists to both diagnose and treat patient's injuries. However, it is my opinion that many people are not aware of this fact believing instead that they must see a doctor before going to a physiotherapist. It is probable that these same people do not know that under New Zealand law physiotherapy treatment is essentially free if Accident Compensation Corporation (ACC) accepts a person's claim that their injury was the result of an accident.

According to members of the research advisory group, many adolescents who have played rugby reasonably successfully through primary school and the early years of secondary school suddenly become despondent and leave the game around the age of fifteen or sixteen. Three members of the research advisory group suggested the reasons for this phenomenon lie in the fact that as boys get too big for the specified weight grades they become reluctant to make the transition into the open grades because they think they will get injured. I'm not sure that this is the full answer, and even if it is a part answer I am wondering if there some other grade or competition that could accommodate these boys. I think there is a need to explore this particular phenomenon further, especially in light of the New Zealand government's concern about less-than-optimum levels of physical activity across nearly all sectors of our society and the impact this will have on health costs in the future.

Lastly, there exists an area for future research that specifically relates to the parents of adolescents who are highly ranked sports persons. Donaldson (2000) and Côté et al. $(2003,2002)$ have shown that parents of such athletes need to dispense high amounts of emotional support. Someone interested in socialization theory could try to find out more about the nature of all the other costs required for parents in such a situation. Studying the role of parents of highly ranked adolescent athletes playing team sports could be one study while another study could involve parents of adolescent athletes playing individual sports. 


\section{Summary}

Much of the information contained in this research project can be regarded as new learning, as to date, schoolboy rugby in New Zealand and elsewhere has not been a popular subject for either new or even experienced researchers.

The data collected from the young men in this study suggest that the experience of being selected and playing for a secondary school First XV team can be a hugely affirming experience. And, for the six research participants, their membership of a secondary school First XV team was effectively the first-step of a journey that had been in their minds for some time. Their First XV membership at their respective colleges, and their growth as rugby players, helped to secure them a place at the Wellington Rugby Academy.

Members of the Rugby Academy can be likened to being young apprentices in the world of professional sport, as their strength, stamina and commitment to their sport is continually being enhanced. The getting up at a quarter to six to get ready for seven o'clock training five mornings a week and the training sessions four nights a week, two for the Rugby Academy and two for their respective clubs, is an accepted part of the apprenticeship process. In the not too distant future, I am expecting to see at least four of the young men I interviewed running out of the tunnel and onto the turf at the Westpac Stadium as members of the Wellington Lions team (or perhaps another province's team). They may even become members of the Hurricanes (or another Super Fourteen team) and from there, one, two or even three of these exceptional young men may get to don the black jersey and play for New Zealand. 


\section{APPENDICIES}




\section{Appendix 1: $\quad$ Interview Schedule}

1. What I would like you to do is to tell me about your earliest memories watching or playing rugby. Maybe you could tell me the name of the team you were watching or playing in, where that was and who else was there.

2. Thinking back to the time when you were quite small, say between 3 and 6 years, would you say you were a) an active kid, b) a very active kid, c) a super active kid or d) none of the above type of kid.

3. Is there any one sporting experiences that you had when you were young that sticks in your mind as being particularly enjoyable or even life changing?

4. Thinking about the adults in your life as you were growing up. Are there any particular adults who over the years have really helped you with your rugby? (Parents, grand-parents, uncles, aunts, even other boy's dads/mums)

5. And who was it that suggested you apply for a place at the Wellington Rugby Academy?

6. I see you went to college. Can you tell me what you remember about your very first game of rugby for college.

7. Is there anyone you were playing with during your Third Form year that was a real stand-out player and do you know if he is still playing rugby today?

8. So when you were in the team in Third Form did you have aspirations of playing in the college first XV one day?

9. If you didn't have aspirations then when was it that you started to think that you had the skills to make it and did you then start seriously planning and working so that it would happen? 
10. As a teacher I see the guys out training after school. Sometimes it is quite late by the time they finish and they still have to get home and eat, do homework, maybe help out with chores, talk to parents, brothers and girl friends and who knows what else. How did you manage to fit everything in?

11. Did it get more difficult to fit in everything in Year Eleven, Twelve and Thirteen?

12. Did you have anyone you could turn to during these high-stress times? (parents, teachers, mates, trainer, others)

13. I would like you to imagine it is mid August, two or perhaps three years ago. It is sometime in the middle of the week and on the Saturday coming up it is going to be the Premier 1 Rugby Finals. Your college's first XV against Wellington College/Silverstream (which ever is most appropriate). Can you describe the build-up for a game like that; possibly start at getting yourself to the final training session; would that have been on the Wednesday or Thursday afternoon?

14. Again, I'm interested in finding out if there was any one who helped you out in anyway during the lead up to big games or at times when you were getting ready for rep trials?

15. Are you or were you the sort of person who has or had little sayings that you put up somewhere or kept in your head to help keep you focused on your goals or on some skill you needed to improve on or at?

16. What about during the off season. Did you do any running or gym work? (Did you need someone to push you to do that or were you motivated to keep working at your fitness/skills)

17. What about games of touch at the local park, were you into those? 
18. During your time playing rugby at college did you suffer any injuries that put you out of the competition for a while or that you had to manage carefully? (Did you go anywhere for treatment or see someone about rehabilitation?)

19. During your time at primary school or college was there any time when you looked at a particular All Black and tried to model your rugby on his style or use him as a role-model in any way?

20. At the college I teach at, students are encouraged by the Rector and others to set long-term goals and short term goals and to reward them selves at points along the way. Was goal-setting a strategy you seriously employed at any time when you were at college?

(Did you find that this strategy was something that worked for you?)

21. I teach English to Year Nine and Ten guys, and at least once a month I have someone say; "Oh Miss I don't need to do this stuff 'cause I'm going to be a professional rugby player and make lots of money." What would your advice be to young guys who say things like that?

\section{Extra questions:}

When did you first go to a commercial gym and who took you?

Is the actual venue of any importance to you when you are playing a big game?

How much attention do you pay to the food you eat in the lead up to a game?

Compared to your peers did you go put much during your time at college?

Were you given any special responsibilities in your last year at college?

Do you know if your parents have medical and/or hospital insurance for you while playing rugby at school? 
The Rugby Academy goal: "to provide a select group of young players with the skills, discipline, knowledge and attitude needed to succeed at NPC and Super Twelve level" (wrfu, 2003). I imagine getting to the point where you were able to apply to the Rugby Academy would have taken a lot of discipline on your part already? How disciplined do you think you were during your secondary school years?

Have you heard of the rugby/rugby league academy that operates for Year Thirteen and above students within Aranui High School in Christchurch? Basically the students do only three subjects and the rest of the time is spent on developing rugby skills and doing gym work. Do you think one of the boys' schools in Wellington need to think about putting in place that kind of set up to keep talented boys not only in the game but finding some sort of success in the classroom? 


\section{BIBLIOGRAHY}

Allison, K., Dwyer, J., Goldenberg, E., \& Fein, A. (2005). Male adolescents' reasons for participating in physical activity, barriers to participation, and suggestions for increasing participation. Adolescence, 40(155), 155-171.

Baker, J., Cote, J., \& Abernethy, B. (2003). Sport-specific practice and the development of expert decision-making in team ball sports. Journal of Applied Sport Psychology, 14, 12-25.

Baker, J., \& Horton, S. (2004). A review of primary and secondary influences on sport expertise. High Ability Studies, 15(2), 211-228.

Barber, H., Sukhi, H., \& White, S. (1999). The influence of parent-coaches on participant motivation and competitive anxiety in youth sport behaviours. Journal of Sport Behaviour, 22(2), 162-180.

Bloom, B. (Ed.). (1985). Developing Talent in Young People. New York: Ballantine Books.

Brustad, R. (1996). Attraction to physical activity in urban schoolchildren: Parental socialization and gender influences. Research Quarterly for Exercise and Sport, 67(3), 316-324.

Burrell, G., \& Morgan, G. (1979). Sociological Paradigms and Organisational Analysis. London: Heinemann.

Coakley, J. (1992). Burnout among adolescent athletes: A personal failure or social problem? Sociology of Sport Journal, 9(3), 271-285.

Coakley, J. (1998). Sport in Society: Issues and controversies (6th. ed.). San Francisco: Irwin McGraw-Hill.

Coleman, J., \& Hendry, L. (1990). The Nature of Adolescence (2nd. ed.). London: Routledge.

Côté, J. (1999). The influence of family in the development of talent in sports. The Sports Psychologist(13), 395-417.

Côté, J., Baker, J., \& Abernethy, B. (2003). From play to practice: A developmental framework for the acquisition of expertise in team sports. In J. Starkes \& K. Ericsson (Eds.), Expert performances in sports: Advances in research on sport expertise.

Champaign: Human Kinetics.

Côté, J., \& Hay, J. (2002). Children's involvement in sport: A developmental perspective. In J. Silva \& D. Stevens (Eds.), Psychological Foundations of Sport (pp. 484-502). Moston: Merrill. 
Danish, S. J. (2002). Teaching life skills through sport. In M. Gatz, M. A. Messner \& S. Ball-Rokeach (Eds.), Paradoxes of Youth and Sport. Albany: State University of New York Press.

Deci, E., \& Ryan, R. (1991). Intrinsic Motivation and Self-determination in Human Behaviour. New York: Plenum Press.

Denzin, N. K., \& Lincoln, Y. S. (2003). Introduction: The discipline and practice of qualitative research. In N. K. Denzin \& Y. S. Lincoln (Eds.), Handbook of Qualitative Research: Strategies of qualitative inquiry (2nd. ed.). Thousand Oaks: Sage.

Donaldson, N. (2000). High Performance Sport: The athlete's perspective. Unpublished Master of Leisure Studies, University of Waikato, Hamilton, New Zealand.

Duda, J. (1992). Motivation in sport settings: A goal perspective analysis. In G. Roberts (Ed.), Motivation in Sport and Exercise. Champaign: Human Kinetics.

Ericsson, K. (1996). The acquisition of expert performance: An introduction to some of the issues. In K. Ericsson (Ed.), The Road to Excellence: The acquisition of expert performance in the arts and sciences, sports and games. Manwah: Lawrence Erlbaum.

Fergusson, D. M., Lynskey, M. T., \& Horwood, L. J. (1994). A 15 year longitudinal study. Journal of Child Psychology and Psychiatry, 35(6), 1123 -1140.

FitzSimons, P. (1996). The Rugby War. Sydney: HarperSports.

Foley, D. (1990a). The great American football ritual: Reproducing race, class, and gender inequality. Sociology of Sport Journal, 7(2), 111-135.

Foley, D. (1990b). Learning Capitalist Culture: Deep in the heart of Tejas. Philadelphia: University of Pennsylvania Press.

Fredricks, J., Alfeld-Liro, C., Hruda, L., Eccles, J., Patrick, H., \& Ryan, A. (2001). A qualitative exploration of adolescents' commitment to athletics and the arts. Journal of Adolescent Research, 17(1), 68-97.

Gagné, F. (1991). Toward a differentiated model of giftedness and talent. In N. Colangelo \& G. Davis (Eds.), Handbook of Gifted Education. Boston: Allyn and Bacon.

Gilson, C. H. (2001). Peak performing organisation theory. In C. H. Gilson (Ed.), Peak Performance: Business lessons from the world's top sporting organisations. London: Harperbusiness.

Gould, D., Dieffenbach, K., \& Moffett, A. (2001). The development of psychological talent in U.S. Olympic champions: Final grant report: Department of Exercise \& Sport Science, University of North Carolina. 
Gould, D., Dieffenbach, K., \& Moffett, A. (2002). Psychological characteristics and their deveopment in Olympic champions. Journal of Applied Sport Psychology, 14(3), 172-204.

Gould, D., Feltz, D., Horn, T., \& Weiss, M. (1985). Motives for participation in competitive youth swimming. The International Journal of Sport Psychology (16), 126-140.

Harlick, M. (1999). Parental influence in youth sport: Effects on athletic burn-out. Unpublished Master of Physical Education, University of Otago, Dunedin, New Zealand.

Harlick, M., \& McKenzie, A. (2000). Burnout in junior tennis: A research report. New Zealand Journal of Sports Medicine, 28(2), 36-39.

Heitman, R., Pugh, S., Kovaleski, P., Norell, P., \& Vicory, J. (2005). Effects of specific verses variable parctice on the retention and transfer of a continuous motor skill. Perceptual and Motor Skills, 100(3), 1107-1125.

Henderson, K. A. (1991). Dimensions of Choice: A qualitative approach to recreation, parks and leisure research. State College: Venture.

Hirschhorn, D., \& Loughead, T. (2000). Parental impact on youth participation in sport: The physical educator's role. Journal of Physical Recreation, Recreation and Dance, 71(9), 26-29.

Howard, S., \& Johnson, B. (2001). Promoting resilience in young people: The role of the family, the school and the community. Paper presented at the Second National Youth Development Conference, Glenelg, South Australia.

Howe, B. (1990). Coaching Effectiveness. New Zealand Journal of Health, Physical Education and Recreation, 23(3), 4-8.

Jackson, C., \& Bisset, M. (2005). Gender and school choice: Factors influencing parents when choosing single-sex or co-educational independent schools for their children. Cambridge Journal of Education, 35(2), 195-211.

Kimiecik, J., \& Horn, T. (1998). Parental beliefs and children's moderate-to -vigorous physical activity. Research Quarterly for Exercise and Sport, 69(2), 163-175.

Lashlie, C. (2005). He'll be OK: Growing gorgeous boys into good men. Auckland: Harper-Collins.

Leff, S., \& Hoyle, R. (1995). Young athletes' perceptions of parental support and pressure. Journal of Youth and Adolescence, 24(2), 187-204.

Light, R., \& Kirk, D. (2000). High school rugby, the body and the reproduction of hegemonic masculinity. Sport, Education and Society, 5(2), 163-177.

Mac an Ghaill, M. (1996). Understanding Masculinities: Social relations and cultural arena. Buckingham: Open University Press. 
MacPhail, A., \& Kirk, D. (2006). Young people's socialisation into sport: Experiencing the specialising phase. Leisure Studies, 25(1), 57-74.

Maykut, P., \& Morehouse, R. (1994). Beginning Qualitative Research: A Philosophic and Practical Guide. London: The Falmer Press.

McLean, G. (2005). Sport, recreation and physical activity in New Zealand, Presentation to Leisure and Heritage students Victoria University. Victoria University.

Messner, M. (1990). Boyhood, organised sports, and the construction of masculinities. Journal of Youth and Adolescence, 18(4), 416-445.

Palenski, R., Chester, R., \& McMillan, N. (2006). Men in Black. Auckland: Hachette Livre NZ Ltd.

Paterson, G. (1999). Coaching for the development of athlete self-esteem: The relationship between the self-perceptions of junior cricketers and their perceptions of coaching behaviour. Sociology of Sport Online, 2(1).

Phillips, G. (1994). Rugby. In W. Vamplew \& B. Stoddart (Eds.), Sport in Australia: A social history. Melbourne: Cambridge University Press.

Phillips, J. O. (1984). Rugby, War and the Mythology of the New Zealand Male. New Zealand Journal of History, 18(2).

Phillips, J. O. (1996). A Man's Country? The image of the Pakeha male - A history (revised edition). Auckland: Penguin Books.

Pickworth, G., \& Moine, D. (1991). How super-achievers outperform others. Successful selling and managing, August.

Pugh, S., \& Alford, A. (2004). Teaching touch rugby in Physical Education classes. Strategies, 17(5), 7-10.

Pugh, S., Wolff, R., DeFrancesco, C., Gilley, W., \& Heitman, R. (2000). A case study of elite male youth baseball athletes' perception of the youth sports experience. Education, 120(4), 773-780.

Reed, W., \& Swan, A. (1969). 100 years of Rugby: The birth and evolution of our national game. Nelson: Lucas \& Son.

Romanos, J., ed., \& Quinn, K. (1999). Legends of the All Blacks. Auckland: Hodder Moa Beckett.

Ryan, C. (1999). Athletic burnout: Relationship with goal orientations and motivational climate. Unpublished Master of Physical Education, University of Otago, Dunedin, New Zealand. 
Ryan, G. (2005a). The Contest for Rugby Supremacy: Accounting for the 2005 All

Blacks. Christchurch: Canterbury University Press.

Ryan, G. (2005b). Rural myth and urban actuality: The anatomy of the All Black and New Zealand rugby 1884 -1938. In G. Ryan (Ed.), Tackling Rugby Myths: Rugby and New Zealand society 1854 - 2004. Dunedin: University of Otago Press.

Scanlan, T., \& Simons, J. (1992). The construct of sport enjoyment. In G. Roberts (Ed.), Motivation in Sport and Exercise. Champaign: Human Kinetics.

Silverman, P., \& Morehouse, R. (2005). Doing Qualitative Research (2nd. ed.). London: Sage.

Smith, A. (1998). Peer relationship and physical activity participation in early adolescence, Dissertation Abstracts International: US: University Microfilms International.

Sparkes, A. C. (1992). Research in Physical Education and Sport: Exploring alternative visions. London: The Falmer Press.

Sport and Recreation New Zealand. (2004a). Linking promise to the podium. Retrieved 15 September, 2005, from www.sparc.org.nz

Sport and Recreation New Zealand. (2004b). Trends in participation in sport and active leisure 1997-2001. Retrieved 10 June, 2005, from www.sparc.org.nz

Sport and Recreation New Zealand. (2005). Talent development. Retrieved 2 July, 2005, from www.sparc.org.nz

Stevenson, C. (1999). Becoming an international athlete: Making decisions about identity. In J. Coakley \& P. Donnelly (Eds.), Inside Sports. New York: Routledge.

Stiles, D., Gibbons, J., Sebben, D., \& Wiley, D. (1999). Why adolescent boys dream of becoming professional athletes. Psychological Reports, 84, 1075-1085.

Swain, J. (2000). "The money's good, the fame's good, the girls are good': The role of playground football in the construction of young boys' masculinity in a junior school. British Journal of Sociology of Education, 21(1), 95-109.

Swain, J. (2002). The resources and strategies boys use to establish status in a junior school without competitive sport. Journal of Youth and Adolescence, 23(1), 91-108.

Vincent, G. T. (2005). To uphold the honour of the province: Football in Canterbury, c.1854-c.1890. In G. Ryan (Ed.), Tackling Rugby Myths: Rugby and New Zealand society 1854-2004. Dunedin: University of Otago Press.

Weiner, B. (1974). Achievement motivation and attribution theory. New Jersey: General Learning Press.

Weiss, M., \& Ferrer-Cajae, E. (2002). Motivational orientations and sport behaviour. In T. Horn (Ed.), Advances in Sport Psychology. Champaign: Human Kinetics. 
Weiss, M., \& Gill, D. (2005). What goes around comes around: Re-emerging themes in sport and exercise psychology. Research Quarterly for Exercise and Sport, 76(2), S71.

Wellington Rugby Football Union. (2003). Rugby Academy. Retrieved 25 June, 2005, from www.wrfu.co.nz

Wiersma, L., \& Sherman, C. (2005). Volunteer youth sport coaches' perspectives of coaching education/certificates and parental codes of conduct. Research Quarterly for Exercise and Sport, 76(3), 324-338. 